\title{
To What Extent Are the Terminal Stages of Sepsis, Septic Shock, Systemic Inflammatory Response Syndrome, and Multiple Organ Dysfunction Syndrome Actually Driven by a Prion/Amyloid Form of Fibrin?
}

\author{
Douglas B. Kell, DSc, MA, DPhil ${ }^{1,2,3}$ Etheresia Pretorius, $\mathrm{PhD}^{4}$
}

1 School of Chemistry, The University of Manchester, Manchester, United Kingdom

2 Manchester Institute of Biotechnology, The University of Manchester, Manchester, United Kingdom

${ }^{3}$ Centre for Synthetic Biology of Fine and Speciality Chemicals, The University of Manchester, Manchester, United Kingdom

${ }^{4}$ Department of Physiological Sciences, Stellenbosch University, Matieland, South Africa

Semin Thromb Hemost 2018;44:224-238.

\begin{abstract}
Address for correspondence Douglas B. Kell, DSc, MA, DPhil, Manchester Institute of Biotechnology, The University of Manchester, 131, Princess St, Manchester M1 7DN, United Kingdom (e-mail: dbk@manchester.ac.uk).
\end{abstract}

\begin{abstract}
A well-established development of increasing disease severity leads from sepsis through systemic inflammatory response syndrome, septic shock, multiple organ dysfunction syndrome, and cellular and organismal death. Less commonly discussed are the equally well-established coagulopathies that accompany this. We argue that a lipopolysaccharide-initiated (often disseminated intravascular) coagulation is accompanied by a proteolysis of fibrinogen such that formed fibrin is both inflammatory and resistant to fibrinolysis. In particular, we argue that the form of fibrin generated is

Keywords

- sepsis

- SIRS

- dormant bacteria

- septic shock

- MODS amyloid in nature because much of its normal $\alpha$-helical content is transformed to $\beta$-sheets, as occurs with other proteins in established amyloidogenic and prion diseases. We hypothesize that these processes of amyloidogenic clotting and the attendant coagulopathies play a role in the passage along the aforementioned pathways to organismal death, and that their inhibition would be of significant therapeutic value, a claim for which there is considerable emerging evidence.
\end{abstract}

Sepsis is a disease with high mortality. ${ }^{1-7}$ However, the original notion of sepsis as the invasion of blood and tissues by pathogenic microorganisms has long come to be replaced, in the antibiotic era, by the recognition that in many cases, the main causes of death arise not so much from the replication of the pathogen per se but from the host's "innate immune" response to the pathogen. ${ }^{8-11}$ In particular, microbial replica- tion is not even necessary (and most bacteria in nature are dormant $^{12-16}$ ), as this response is driven by very potent ${ }^{17}$ inflammation-inducing agents such as the lipopolysaccharides (LPSs) of gram-negative bacteria ${ }^{18}$ and equivalent cell wall materials such as lipoteichoic acids from gram-positive bacteria. $^{19-22}$ To this end, such release may even be worsened (i.e., the Jarisch-Herxheimer reaction ${ }^{23-26}$ ) by antibiotic

Copyright @ 2018 by Thieme Medical Publishers, Inc., 333 Seventh Avenue, New York, NY 10001, USA. Tel: +1(212) 584-4662.
Issue Theme Editorial
Compilation V; Guest Editors: Emmanuel J. Favaloro, PhD, FFSc (RCPA), and Giuseppe Lippi, MD.
August 4, 2017

DOI https://doi.org/ $10.1055 / \mathrm{s}-0037-1604108$ ISSN 0094-6176. 
Strong infection

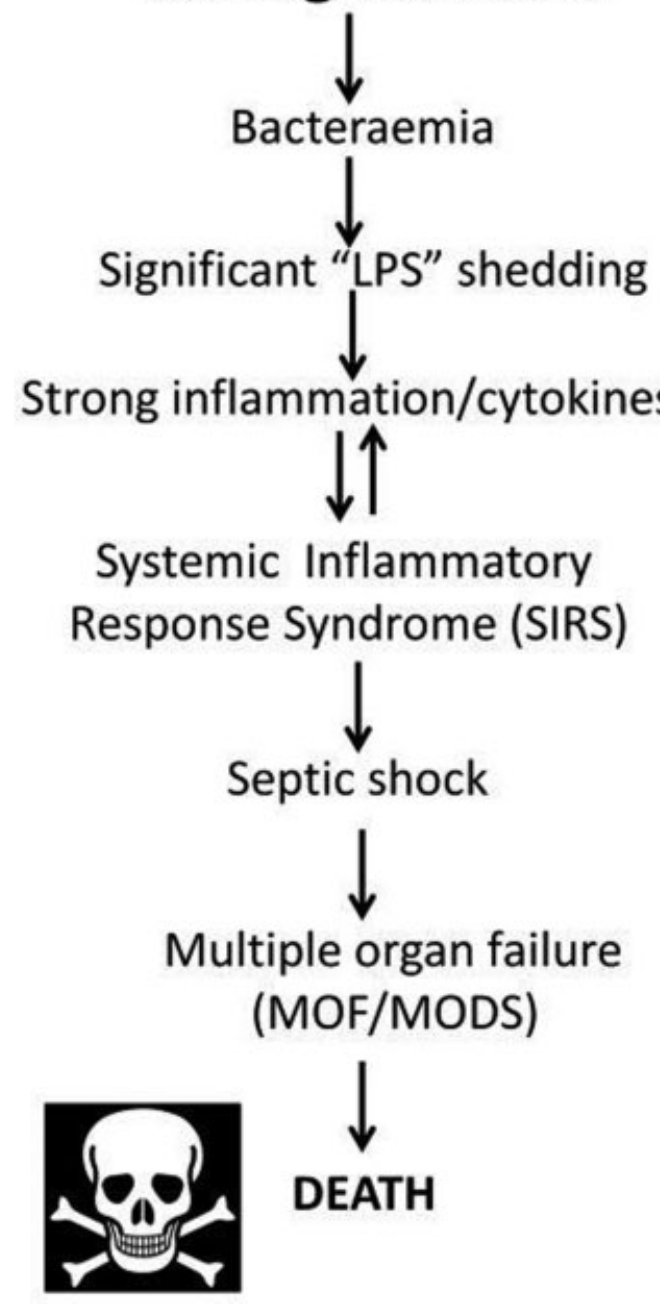

Fig. 1 A standard cascade illustrating the progression of infection through sepsis, systemic inflammatory response syndrome, and death.

therapy. ${ }^{27-30}$ In unfavorable cases, this leads to an established cascade (-Fig. 1 ( $^{31}$ in which the innate immune response, involving proinflammatory cytokines such as interleukins 6,8 , and $1 \beta$, monocyte chemoattractant protein-1, and tissue necrosis factor $\alpha{ }^{32}$ becomes a "cytokine storm"33-37 leading to a "systemic inflammatory response syndrome" (SIRS), ${ }^{38-43}$ septic shock, ${ }^{4}$ multiple organ failure ${ }^{44}$ (MOF, also known as multiple organ dysfunction syndrome, MODS ${ }^{45,46}$ ), and finally organismal death. All of the above is well known and may be taken as a noncontroversial background. Nevertheless, it is still unclear whether apoptotic ${ }^{47}$ and necrotic ${ }^{48}$ cell death is minimal ${ }^{49}$ or significant. Despite this knowledge, "the recent inability of activated protein $C$ to show an outcome benefit in a randomized controlled multicenter trial ${ }^{2}$ and the subsequent withdrawal of the product from commercial use add to the growing stockpile of failed therapeutics for sepsis." ${ }^{\circ 0}$ (This last failure was probably due to an excessively anticoagulant activity.)

Most recently ${ }^{51}$ (but see also Churpek et al $^{52}$ ), definitions of sepsis have come to be based on organ function and the Sequential (Sepsis-Related) Organ Failure Assessment (SOFA) Scores. ${ }^{53}$ These latter take into account the multisystem nature of sepsis and include respiratory, hemostatic (but only based on platelet counts), hepatic, cardiovascular, renal, and central nervous system measurements. A SOFA score of 2 or greater typically means at least a $10 \%$ mortality rate. Specifically, sepsis is defined as a life-threatening organ dysfunction caused by a dysregulated host response to infection. Septic shock is defined as a subset of sepsis in which underlying circulatory and cellular metabolism abnormalities are profound enough to increase mortality substantially.

- Table 1 (based on Vincent et $\mathrm{al}^{53}$ ) shows the potential values that contribute to the SOFA score.

Absent from - Fig. 1, and from the usual commentaries of this type, is any significant role of coagulopathies, although these too are a well-established accompaniment of SIRS/sepsis, ${ }^{54-69}$ and they will be our focus here. They

Table 1 Potential values that contribute to the SOFA score ${ }^{\text {a }}$

\begin{tabular}{|c|c|c|c|c|}
\hline SOFA score & 1 & 2 & 3 & 4 \\
\hline $\begin{array}{l}\text { Respiration } \\
\mathrm{PaO}_{2} / \mathrm{FiO}_{2} \\
(\mathrm{~mm} \mathrm{Hg})\end{array}$ & $<400$ & $<300$ & $\begin{array}{l}<200 \\
\text { (with respiratory support) }\end{array}$ & $\begin{array}{l}<100 \\
\text { (with respiratory support) }\end{array}$ \\
\hline $\begin{array}{l}\text { Coagulation } \\
10^{-3} / \text { platelets } / \mathrm{mm}\end{array}$ & $<150$ & $<100$ & $<50$ & $<50$ \\
\hline $\begin{array}{l}\text { Liver } \\
\text { Bilirubin } \mathrm{mg} / \mathrm{dL} \\
(\mu \mathrm{M})\end{array}$ & $\begin{array}{l}1.2-1.9 \\
(20-32)\end{array}$ & $\begin{array}{l}2-5.9 \\
(33-101)\end{array}$ & $\begin{array}{l}6-11.9 \\
(102-204)\end{array}$ & $\begin{array}{l}>12 \\
(>204)\end{array}$ \\
\hline $\begin{array}{l}\text { Cardiovascular } \\
\text { Hypotension }\end{array}$ & $\begin{array}{l}\mathrm{MAp}<70 \\
\mathrm{~mm} \mathrm{Hg}\end{array}$ & $\begin{array}{l}\text { Dopamine } \leq 5^{\mathrm{b}} \text { or } \\
\text { dobutamine } \\
\text { (any dose) }\end{array}$ & $\begin{array}{l}\text { Dopamine }>5 \\
\text { or epinephrine } \leq 0.1 \text { or } \\
\text { norepinephrine } \leq 0.1\end{array}$ & $\begin{array}{l}\text { Dopamine }>15 \\
\text { or epinephrine }>0.1 \text { or } \\
\text { norepinephrine }>0.1\end{array}$ \\
\hline $\begin{array}{l}\text { CNS } \\
\text { Glasgow Coma Score }\end{array}$ & $13-14$ & $10-12$ & $6-9$ & $<6$ \\
\hline $\begin{array}{l}\text { Renal } \\
\text { Creatinine, mg/dL } \\
(\mu \mathrm{M}) \text { or urine output }\end{array}$ & $\begin{array}{l}1.2-1.9 \\
(110-170)\end{array}$ & $\begin{array}{l}2-3.4 \\
(171-299)\end{array}$ & $\begin{array}{l}3.5-4.9 \\
(300-440) \\
\text { Or }<500 \mathrm{~mL} / \mathrm{d}\end{array}$ & $\begin{array}{l}>5 \\
(>440) \\
\text { or }<200 \mathrm{~mL} / \mathrm{d}\end{array}$ \\
\hline
\end{tabular}

Abbreviations: CNS, central nervous system; SOFA, Sequential (Sepsis-Related) Organ Failure Assessment.

a Based on Vincent et al ${ }^{53}$ and shows the potential values that contribute to the SOFA score.

${ }^{\mathrm{b}}$ Catecholamine and adrenergic agents administered for at least 1 hour; doses in $\mu \mathrm{g} / \mathrm{kg} / \mathrm{min}$. 
form part of an emerging systems biology analysis, ${ }^{16,18,70-80}$ in which iron dysregulation and an initially minor infection (e.g., in rheumatoid arthritis ${ }^{81,82}$ ) are seen to underpin the etiology of many chronic inflammatory diseases normally considered (as once were gastric ulcers ${ }^{83}$ ) to lack a microbial component.

Here we develop these ideas for those conditions that are recognized as involving a genuine initial microbial invasion, together with sepsis and inflammation driven (in particular) by the cell wall components of bacteria (although we note that the same kinds of arguments apply to viruses ${ }^{84}$ and to other infections).

\section{Normal Blood Coagulation and Coagulopathies}

Historically, there are two main pathways of activation described that lead "normal" blood coagulation to form a clot, as occurs, for example, in response to vessel wall damage or exposure of blood to negatively charged surfaces. They have been expertly reviewed many times ${ }^{85-90}$ (e.g., are known in the older literature, respectively, as "extrinsic" and "intrinsic" pathways). - Fig. 2 shows a basic model of coagulation (redrawn from Kell and Pretorius ${ }^{74}$ under a CC-BY license); typically, assembly of fibrin fibers proceeds in a stepwise fashion. In short, after damage to a blood vessel, collagen is exposed and factor (F) VII interacts with tissue factor (TF), forming a complex called TF-FVIIa. FXa and its cofactor Va form the prothrombinase complex and activate thrombin through prothrombin. Finally, the terminal stages of the coagulation pathway happens, where a cross-linked fibrin polymer is formed as a result of fibrinogen (typically present in plasma at $2-4 \mathrm{~g} / \mathrm{L}$ ) conversion to fibrin and crosslinking due to the activation of FXIII, a transglutaminase. Thrombin activates FXIII into FXIIIa, which, in turn, acts on soluble and insoluble fibrin to polymerize it into insoluble cross-linked fibrin clot. This fibrin clot, when viewed under a scanning electron microscope, consists of individually visible fibrin fibers, discussed in the next paragraphs (see - Fig. 3A for a representative healthy clot structure created when thrombin is added to plasma. ${ }^{74,91-93}$

The normal picture of fibrinogen polymerization involves the removal of two fibrinopeptides (i.e., fibrinopeptides $A$ and B) from fibrinogen, which is normally rich in $\alpha$-helices, leading to its self-association through "knobs and holes," but with otherwise no major changes in secondary structure. ${ }^{77,80}$

Coagulopathies occur when the rate of clot formation or dissolution is unusually fast or slow, and in the case of chronic inflammatory diseases, these seem largely to coexist as hypercoagulation and hypofibrinolysis, arguably implying a common cause. ${ }^{74}$ In a series of papers, we have shown in several diseases, such as stroke, ${ }^{94-96}$ type 2 diabetes, ${ }^{93,97}$ Alzheimer's disease, ${ }^{79,98,99}$ and hereditary hemochromatosis, ${ }^{92}$ that the fibrin clots induced by added thrombin adopted the form of "dense matted deposits" instead of their usual "spaghetti-like" appearance. The same kinds of effect could also be induced by unliganded (i.e., free) iron, ${ }^{92,100-102}$ although no molecular explanation was (or could be) given. We pick this up in the Amyloid-Like Conformational Transitions in Fibrin(ogen) section. First however, we need to deal with two other topics.

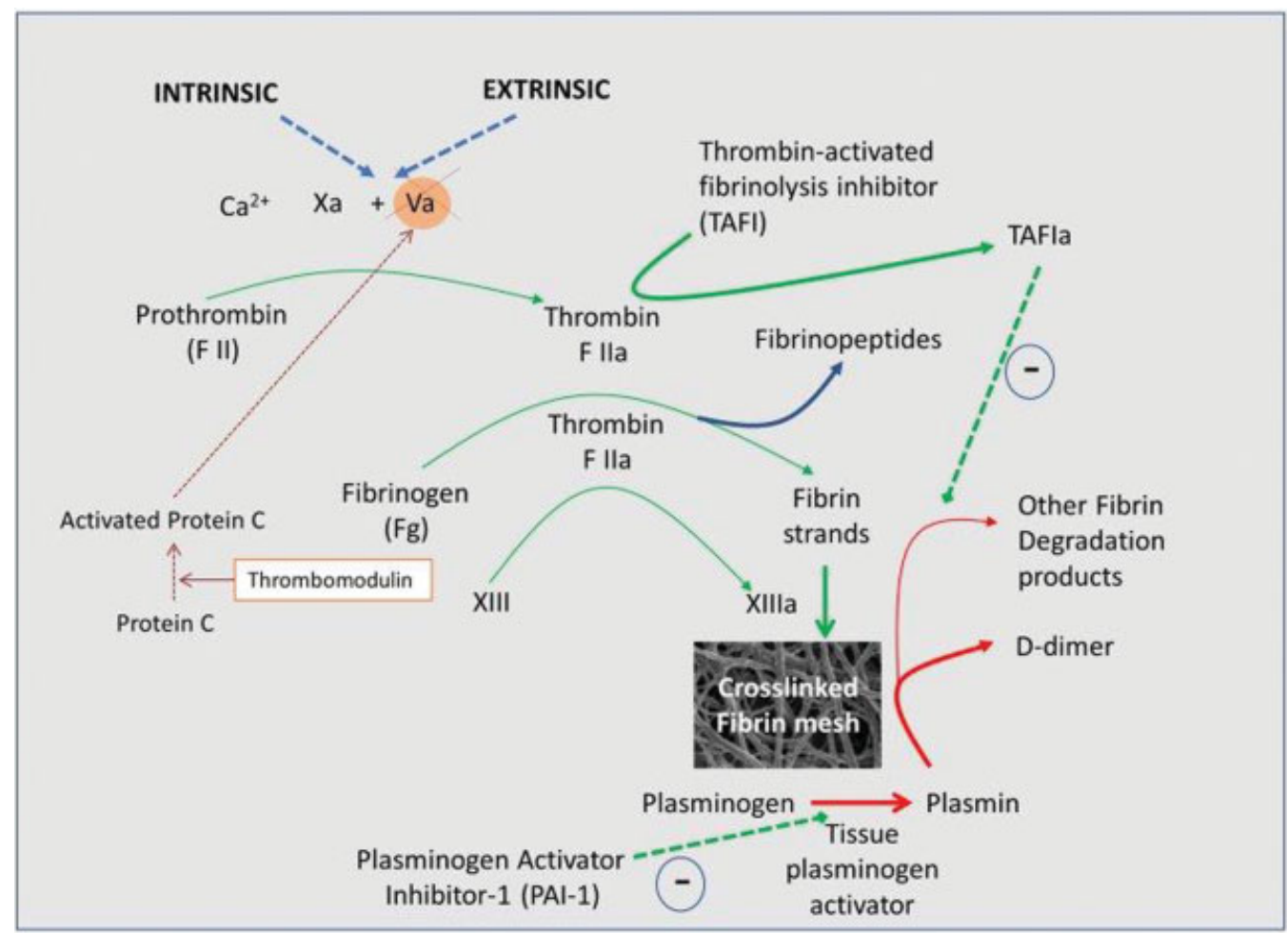

Fig. 2 The classical coagulation pathways, where assembly of fibrin fibers proceeds in a stepwise fashion (redrawn from Kell and Pretorius 74 under an open access CC-BY license). 

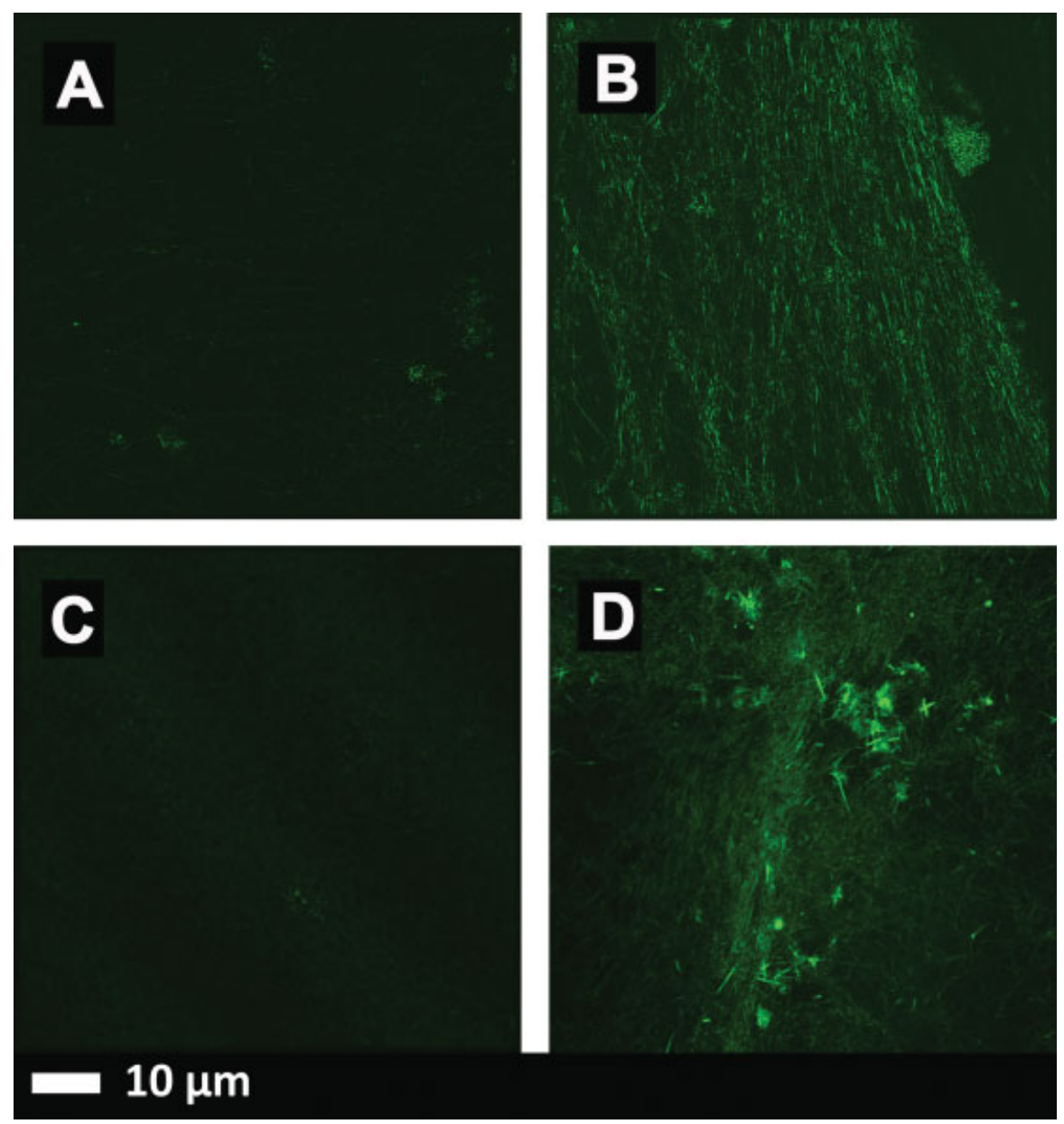

Fig. 3 The results of thrombin-mediated blood clotting. (A-C) Micrographs taken with a Zeiss LSM 800 superresolution Airyscan confocal microscopy using the $\alpha$ Plan-Apochromat 63x/1.46 Oil DIC M27 Elyra objective. (D) Micrograph taken with a Zeiss LSM 510 META confocal microscope with a Plan-Apochromat $63 x / 1.4$ Oil DIC objective. (A) Healthy platelet poor plasma (PPP) with added thioflavin T (ThT) (5- $\mu \mathrm{M}$ exposure concentration) and thrombin. (B) The same PPP, with added lipopolysaccharide (LPS) $(0.2 \mathrm{ng} / \mathrm{L}$ exposure concentration), followed by addition ThT and thrombin. (C) The same PPP, with added LPS followed by LPS-binding protein ( $2 \mathrm{ng} / \mathrm{L}$ final exposure concentration) followed by addition ThT and thrombin. (D) PPP, with added LPS ( $0.2 \mathrm{ng} / \mathrm{L}$ exposure concentration), followed by addition ThT and thrombin.

\section{Endotoxin-Induced “Disseminated Intravascular Coagulation"}

Endotoxin (LPS) may also induce a runaway form of hypercoagulation ${ }^{57,103-117}$ known as disseminated intravascular coagulation (DIC). There is significant evidence now that DIC is reasonably well defined ${ }^{46,118-120}$ and that it can directly lead to MOF and death (Cunningham and Nelson, ${ }^{121}$ and see the following). We hypothesize here that the form of clotting in DIC in fact involves autocatalytic fibrin(ogen) selforganization leading to amyloid formation, which is consistent with the faster clot formation in the presence of endotoxin $^{98}$ and which we have recently shown can occur in vitro with miniscule amounts of LPS ${ }^{80}$ In particular, this may be a major contributor to the various stages of sepsis, SIRS, MODS, and ultimately of organismal death.

\section{Prions, Protein Free Energies, and Amyloid Proteins}

Although it was originally shown that at least some proteins, when denatured and renatured, could revert to their original conformation, ${ }^{122,123}$ implying that this was (isoenergetic with) the one of lowest free energy, this is now known not to be universal. Leaving aside chaperones and the like, one field in which proteins of the same sequence are well known to adopt radically different conformations, with a much more extensive $\beta$-sheet component (that is indeed thermodynamically more stable), is that of prion biology. ${ }^{124,125}$ Thus, the prion protein is normally in an $\alpha$-helix-rich conformation known as $\operatorname{PrP}^{\mathrm{c}}$. However, it can also adopt a proteinase K-resistant form of the same sequence, known as $\mathrm{PrP}^{\mathrm{Sc}}$. 126-131 The $\operatorname{PrP}^{\mathrm{c}}$ and $\operatorname{PrP}^{\mathrm{sc}}$ conformations and the catalysis of the conversion to itself by the latter of the former are very well known. The key point for us here, however, is indeed that this definitely implies ${ }^{77,124,125,128,132-136}$ that proteins that may initially fold into a certain, ostensibly "native," conformation can in fact adopt stable and more $\beta$-sheet-rich conformations of a lower free energy, separated from that of the original conformation by a potentially significant energy barrier.

\section{Amyloid-Like Conformational Transitions in Fibrin(ogen)}

As mentioned earlier, the general view (also see the following) is that no major secondary structural changes occur during 
normal fibrin formation. ${ }^{77,85,87}$ However, we know of at least three circumstances in which fibrin can (i.e., is known to) adopt a $\beta$-sheet-rich conformation: (1) in the case of specific mutant sequences of the fibrinogen a chain, ${ }^{137-143}(2)$ when fibrin is stretched mechanically beyond a certain limit, ${ }^{144-150}$ and (3) when formed in the presence of certain small molecules, including bacterial LPS. ${ }^{76,80,151}$ Thus, it is well established that fibrin can form $\beta$-sheet-rich amyloids, although it is assumed that conventional blood clotting involves only a "knobs-and-holes" mechanism, without any major changes in secondary structure. ${ }^{85-90,152,153}$ We hypothesize here that the "dense matted deposits" seen earlier are in fact $\beta$-sheet-rich amyloids, and that it is this coagulopathy in particular that contributes significantly to the procession of sepsis along or through the cascade of toxicity outlined in -Fig. 1. To be specific, we consider that the binding of the LPS must be to fibrinogen itself since only this is preexisting and we have demonstrated it directly using isothermal calorimetry. ${ }^{80}$ We note too that there is almost no "free" LPS except immediately after its addition/liberation from a bacterium, and that the kinetics of fibrinogen polymerization during thrombin-induced clotting are so fast that it is not necessary to invoke subsequent binding of LPS to protofibrils and so on as part of the mechanism of amyloidogenesis and toxicity.

In particular, thioflavin T (ThT) is a stain whose fluorescence (when excited at 440-450 nm or so) is massively enhanced upon binding to $\beta$-sheet-rich amyloids ${ }^{154-163}$ (whose conformation differs markedly from that of "normal" $\beta$-sheets in proteins, else it would stain most such proteins). - Fig. $3 \mathbf{A}$ to $\mathbf{C}$ show micrographs taken of clots with a Zeiss superresolution microscope using Airyscan technology (Carl Zeiss), and - Fig. 3D shows a micrograph taken using a Zeiss confocal microscope (see legend for specific detail). - Fig. 3A is a micrograph of healthy platelet poor plasma (PPP) with added ThT and thrombin. This is a representative micrograph to show "normal" clot structure, whereas - Fig. 3B and D shows healthy PPP with added LPS and ThT. High-resolution Airyscan technology ( - Fig. 3B) shows ThT binding to areas where $\beta$-sheet-rich amyloids were induced by LPS. - Fig. 3C shows PPP preexposed to LPS, followed by exposure to LPS-binding protein, ThT, and thrombin. LPS-binding protein was able to reverse the formation of the $\beta$-sheet-rich amyloids areas created by preexposure to LPS. Confocal microscopy ( - Fig. 3D) also shows this ThT binding to $\beta$-sheet-rich amyloid areas. However, individual binding areas are not as clearly visible as with the Airyscan technology. Nonetheless, the extent of $\beta$-amyloid formation in the LPS-treated over the two controls is very striking.

We also note the important analyses of Strickland et al to the effect that $\beta$-amyloid can interact with fibrin(ogen $)^{164-170}$ and cause it to become refractory to fibrinolysis. ${ }^{170-173}$

\section{Inflammatory Nature of Fibrin}

The fact that fibrin itself is, or can be, inflammatory is well established ${ }^{108,174-179}$ and does not need further elaboration. Our main point here is that in none of these studies has it been established whether (or to what extent) the fibrin is in an amyloid form or not so far. Certainly, it is very well established that amyloids can be inflammatory. ${ }^{180-183}$

\section{Further Evidence for the "Trigger" Role of LPS in Large-Scale Amyloid Formation}

In our previous studies, ${ }^{80}$ we found that LPS (endotoxin) at a concentration of just $0.2 \mathrm{ng} / \mathrm{L}$ could trigger the conversion of some $10^{8}$ times more fibrinogen molecules, ${ }^{80}$ and that the fibrin fibers so formed were amyloid in nature. (A very large amplification of structural molecular transitions could also be induced by LPS in a nematic liquid crystal. ${ }^{184-186}$ ) Only some kind of autocatalytic processes can easily explain this kind of polymerization, just as occurs in prions, ${ }^{77,129,131}$ where iron may also be involved. ${ }^{70,71,187-189}$ To be explicit, the only feasible explanation is one in which an initial fibrinogen molecule with bound LPS adopts, at least on the loss of its fibrinopeptides, conformations in which the subsequent fibrinopeptide-less fibrinogens must also change their conformations to bind to it and so on as fibrinogens become protofibrils, protofibrils become fibrils, and so on. Put another way, if LPS is the only (and highly substoichiometric) addition to thrombininduced fibrin formation, there must be an "autocatalytic process," somewhat analogous to a prion, that must be taking place since rather than having conventional strands of fibrin, we have amorphous, denatured $\beta$ sheets.

\section{Cytotoxicity of Amyloids}

Cytotoxicity of amyloids is so well known ${ }^{98,182,190-197}$ that it barely needs rehearsing. However, the relative toxicities of soluble material, protofibrils, fibrils, and so on are less well understood, ${ }^{198}$ in part because they can equilibrate with each other even if added as a "pure" component (of a given narrow NB equilibrate range). Although the larger fibrils are much more easily observable microscopically, there is a great deal of evidence that it is the smaller ones that are the more cytotoxic. $^{199-216}$ So far as is known, almost all (cf. Holm et $\mathrm{al}^{217}$ ) the established forms of amyloid are cytotoxic. However, the tests have not yet been performed for the fibrin version since it has only very recently been discovered. ${ }^{77,80}$ This is an urgent task for the future.

\section{Sequelae Consistent with the Role of Amyloids in the "Sepsis Cascade" to Organ Failure and Death}

If vascular or systemic amyloidogenesis really is a significant contributor to the worsening patient conditions as septic shock moves toward MOF/MODS and death, with the cytotoxic amyloids (whether from fibrin and/or otherwise) in effect being largely responsible for the MOF, then one might expect it to be visible as amyloid deposits in organs such as the kidney (whether as biopsies or postmortem). It is certainly possible to find evidence for this, ${ }^{218-223}$ and our proposal is that such amyloid should be sought using ThT or other suitable staining in autopsy tissue. 


\section{Hypo- or Hypertensive States}

A hallmark of most of the chronic, inflammatory diseases that we have considered here and elsewhere (as cited) is that they are either normotensive or (to varying degrees) hypertensive. By contrast, sepsis and septic shock are strongly hypotensive (accompanied by hypoperfusion), ${ }^{224-228}$ and their normalization is considered a crucial factor for lowering mortality. Consequently, this bears a brief discussion. Of course, at one level, it is common in biology that something can be a stimulus (e.g., of blood pressure) at a low concentration and can be an inhibitor at a high concentration (this is known as "hormesis"229-231). At a descriptive level, this is clearly happening here. As it stands, however, we can find no literature that has compared changes in tension as the dose of endotoxin is varied, with the doses given in such studies of endotoxin-induced shock normally being sufficient to induce significant hypotension. $^{232-234}$ It is, however, of considerable interest that this endotoxin-induced hypotension (and other sequelae) could be relieved by antithrombin (e.g., ${ }^{233,235-247}$ ), implying a contributing role for coagulopathies in the hypotension otherwise observed, albeit other mechanisms are possible. ${ }^{238}$

\section{How Might This Understanding Lead to Improved Treatment Options?}

Over the years, there have been many high-profile failures of therapies for various aspects of severe inflammation, sepsis, septic shock, and SIRS. These include therapies aimed at endotoxin itself (Centoxin), ${ }^{248-250}$ and the use of recombinant activated protein $C^{251}$ or Drotrecogin alfa. 2,250,252,253 Anticytokine and anti-inflammatory treatments have also had, at best, mixed results. 254,255

However, the overall picture that we have come to is given in - Fig. 4. This implies that we might hope to stop the progress of the sepsis/SIRS/MODS cascade at any (preferably several ${ }^{256}$ ) of several other places, including through iron chelation, ${ }^{70,71,257,258}$ the use of anti-inflammatory agents, the use of anticoagulants such as heparin ${ }^{178}$ or antithrombin, ${ }^{233,238,243}$ and the use of stimulants of fibrinolysis. ${ }^{259}$ The success of heparin ${ }^{260,261}$ (see also Zarychanski et al, van Roessel et al, and Okamoto et $\mathrm{al}^{262-264}$ ) is especially noteworthy in the context of the present hypothesis, though it may have multiple (not simply directly anticoagulant) actions. ${ }^{265,266}$ The same is true of antithrombin. 233,235-247,267,268 However, antithrombin has also not been efficacious, especially in combination with heparin ${ }^{269}$ and is globally not recommended in sepsis therapy guidelines. ${ }^{4,270}$ Indeed, suppressing coagulation in sepsis globally may be inimical, as it is thought to serve a protective role in the initial stages of the disease. ${ }^{271}$ It is also noteworthy that high-density lipoprotein (HDL) cholesterol is a protective against sepsis ${ }^{18,272-274}$ (HDL are antioxidant ${ }^{275}$ and antiinflammatory ${ }^{276}$ and can also bind and neutralize endotoxin $^{277-279}$ ). Therefore, the beneficial role of certain statins in sepsis ${ }^{280,281}$ should be seen in the context of their much more potent anti-inflammatory role $^{70}$ rather than in any (modest) role involved in lowering overall serum cholesterol. Phospholipid emulsions may also serve. ${ }^{282}$

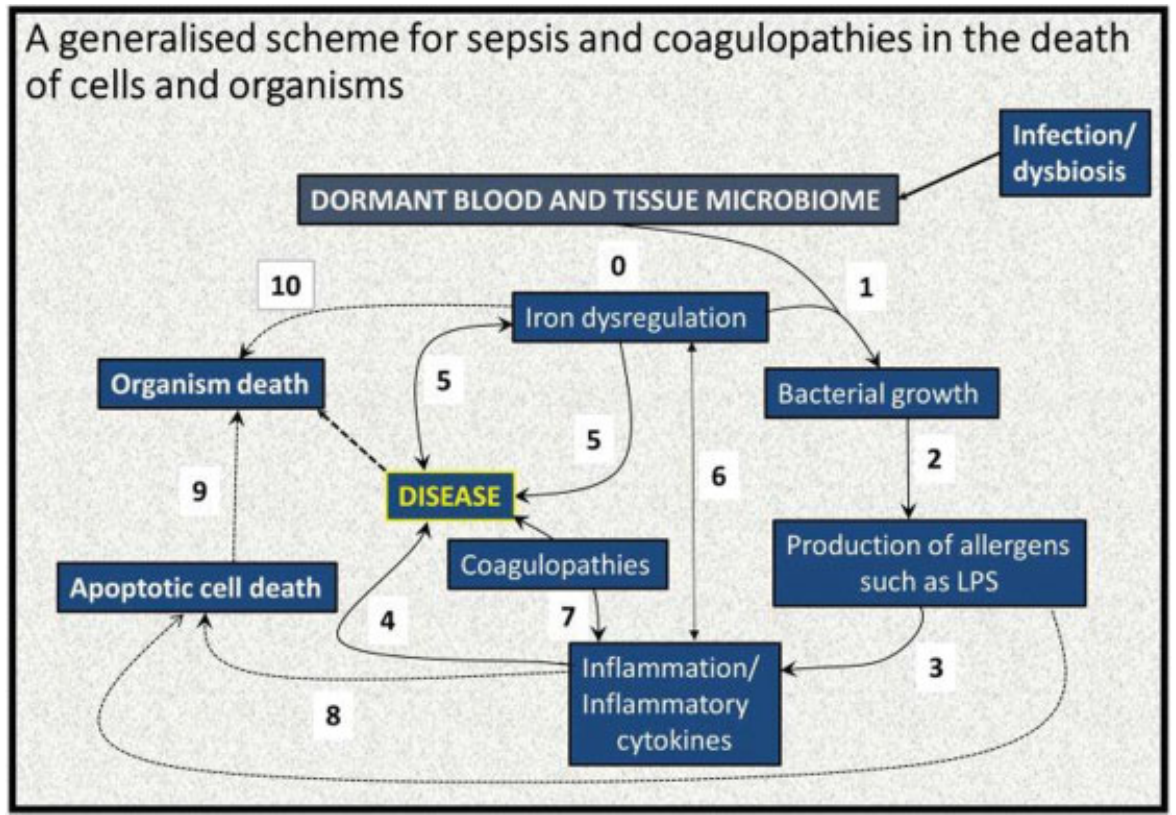

Fig. 4 A systems biology model of the development of coagulopathies during sepsis, systemic inflammatory response syndrome, and multiple organ dysfunction syndrome. An elementary systems biology model of how iron dysregulation can stimulate dormant bacterial growth that can, in turn, lead to antigen production (e.g., of lipopolysaccharide [LPS]) that can then trigger inflammation leading to cell death ${ }^{70,71}$ and a variety of diseases. While it is recognized that this simple diagram is very far from capturing the richness of these phenomena, there is abundant evidence for each of these steps, starting with ( 0 ) an infection/gut dysbiosis and the creation of a (dormant) blood and tissue microbiome. This is typically accompanied by (1) iron dysregulation, which is known to be present in many diseases, as both cause and result (5) and as an important cause of inflammation (6) and even organism death (10). Iron, in turn, feeds bacterial growth (2), leading to production of, for example, LPS with an accompanying upregulated inflammatory cytokine profile (3), leading to disease (4). In inflammation both apoptotic death (8) and coagulopathies (7) are well-known phenomena. In turn, apoptotic death can lead to organism death (9). 


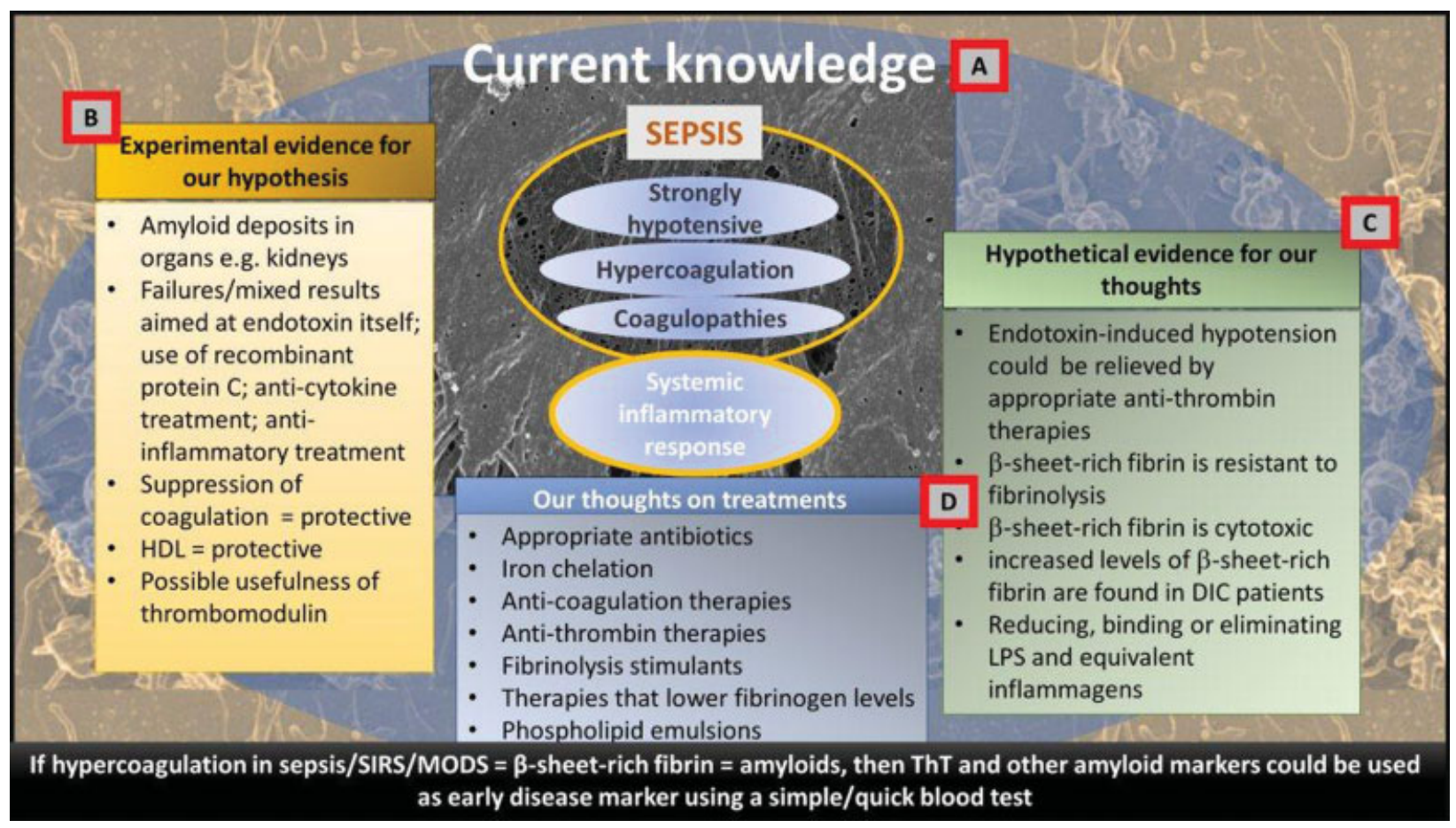

Fig. 5 A schematic representation outlining our hypothesis based on current knowledge (A), experimental evidence for our hypothesis (B), hypothetical evidence (C), and finally our thoughts on (new) treatment regime approaches and early disease diagnosis (D).

We have noted previously (reviewed in Kell and Pretorius ${ }^{74}$ ) that such "dense matter deposits" (now recognized as amyloid forms) are much more resistant to fibrinolysis than is "normal" fibrinogen. The working hypothesis here is that the $\beta$-sheet-rich forms are more resistant to proteolysis because (as in prions, where the structures are known) the residues normally targeted by the relevant proteases are no longer exposed. Clearly, the removal of such structures would benefit from the development of novel proteases to which they are susceptible.

Recombinant soluble human thrombomodulin (TM- $\alpha$ ) is a novel anticoagulant drug and has been found to have significant efficacy in the treatment of sepsis-based DIC, 247,283-293 albeit fully powered randomized trials are awaited, ${ }^{294,295}$ again adding further weight to our hypothesis. As Okamoto et $\mathrm{al}^{264}$ point out, "In the European Union and the USA, the 2012 guidelines of the Surviving Sepsis Campaign do not recommend treatment for septic DIC. ${ }^{4,296}$ In contrast, in Japan, aggressive treatment of septic DIC is encouraged,"297-300 and that "that Japan is one of the countries that most effectively treats patients with septic DIC." ${ }^{264}$ A recent meta-analysis of randomized controlled trials for the efficacy and safety of anticoagulant therapy demonstrated that such therapy has a survival benefit in those with sepsis-induced DIC, but not in the overall population with sepsis or even in populations with sepsis-induced coagulopathy. ${ }^{271}$ We note that the influence of soluble TM may be mediated by its indirect thrombin inhibition by binding and not localizing it to a site where protein $\mathrm{C}$ is activated.

Thus, if it is accepted that the type of fibrin that is formed is substantially of the amyloid variety, then anticoagulant and other drugs that inhibit or reverse such amyloid pro- cesses should also be of value, ${ }^{301}$ as they seem to be in Alzheimer-type dementia. ${ }^{165,302,303}$

\section{Concluding Remarks}

We conclude by showing our line of thought in $\sim$ Fig. 5 . There is by now abundant evidence that coagulopathies involving fibrin clots are a major part of sepsis, SIRS, septic shock, MODS, DIC, and organismal death. We have invoked further evidence that the type of fibrin involved is an amyloid form and have suggested that it is this that is especially damaging. This definitely needs to be tested further, for instance, using appropriate stains ${ }^{155,304}$ and/or X-ray measurements ${ }^{305-307}$ in concert with cellular toxicity assays. The former could easily be performed in or near the intensive therapy unit. LPS and other substances have now been shown to cause anomalous forms of fibrin, which opens up many novels lines of work, such that reducing or eliminating them might be worthwhile, for example, with LPS-binding protein. Finally, as a corollary of the above, we suggest that anticoagulant therapies that inhibit or reverse those $\beta$-amyloid forms of fibrin production will be especially valuable. To this end, lowering the levels of fibrinogen itself would seem to be a desirable aim. ${ }^{308}$

Conflict of Interest

The authors have nothing to disclose.

\section{Ethical Approval Disclosure}

Ethical approval was granted by the University of Pretoria for all human studies (Human Ethics Committee: Faculty of Health Sciences) to Etheresia Pretorius. 


\section{Funding}

We thank the Biotechnology and Biological Sciences Research Council (grant BB/L025752/1) as well as the National Research Foundation (NRF) and Medical Research Council (MRC) of South Africa for supporting this collaboration.

\section{Acknowledgments}

D.B.K. thanks Prof. Nigel Harper for a very useful discussion. We also thank the referees and the journal editors for exceptionally careful and thoughtful reviews that helped improve the manuscript considerably.

\section{References}

1 Martin GS, Mannino DM, Eaton S, Moss M. The epidemiology of sepsis in the United States from 1979 through 2000. N Engl J Med 2003;348(16):1546-1554

2 Ranieri VM, Thompson BT, Barie PS, et al; PROWESS-SHOCK Study Group. Drotrecogin alfa (activated) in adults with septic shock. N Engl J Med 2012;366(22):2055-2064

3 Angus DC, van der Poll T. Severe sepsis and septic shock. N Engl J Med 2013;369(09):840-851

4 Dellinger RP, Levy MM, Rhodes A, et al; Surviving Sepsis Campaign Guidelines Committee including the Pediatric Subgroup. Surviving sepsis campaign: international guidelines for management of severe sepsis and septic shock: 2012. Crit Care Med 2013;41(02):580-637

5 Stevenson EK, Rubenstein AR, Radin GT, Wiener RS, Walkey AJ. Two decades of mortality trends among patients with severe sepsis: a comparative meta-analysis. Crit Care Med 2014;42(03):625-631

6 Fleischmann C, Scherag A, Adhikari NK, et al; International Forum of Acute Care Trialists. Assessment of global incidence and mortality of hospital-treated sepsis. Current estimates and limitations. Am J Respir Crit Care Med 2016;193(03):259-272

7 Beck MK, Jensen AB, Nielsen AB, Perner A, Moseley PL, Brunak S. Diagnosis trajectories of prior multi-morbidity predict sepsis mortality. Sci Rep 2016;6:36624

8 Cohen J. The immunopathogenesis of sepsis. Nature 2002;420 (6917):885-891

9 Bhatia M, Moochhala S. Role of inflammatory mediators in the pathophysiology of acute respiratory distress syndrome. J Pathol 2004;202(02):145-156

10 Russell JA. Management of sepsis. N Engl J Med 2006;355(16): 1699-1713

11 Wiersinga WJ, Leopold SJ, Cranendonk DR, van der Poll T. Host innate immune responses to sepsis. Virulence 2014;5(01):36-44

12 Kaprelyants AS, Gottschal JC, Kell DB. Dormancy in non-sporulating bacteria. FEMS Microbiol Rev 1993;10(3-4):271-285

13 Kell DB, Kaprelyants AS, Weichart DH, Harwood CR, Barer MR. Viability and activity in readily culturable bacteria: a review and discussion of the practical issues. Antonie van Leeuwenhoek 1998;73(02):169-187

14 Lewis K. Persister cells, dormancy and infectious disease. Nat Rev Microbiol 2007;5(01):48-56

15 Buerger S, Spoering A, Gavrish E, Leslin C, Ling L, Epstein SS. Microbial scout hypothesis, stochastic exit from dormancy, and the nature of slow growers. Appl Environ Microbiol 2012;78(09): 3221-3228

16 Kell D, Potgieter M, Pretorius E. Individuality, phenotypic differentiation, dormancy and 'persistence' in culturable bacterial systems: commonalities shared by environmental, laboratory, and clinical microbiology. F1000 Res 2015;4:179
17 Lew WY, Bayna E, Molle ED, et al. Recurrent exposure to subclinical lipopolysaccharide increases mortality and induces cardiac fibrosis in mice. PLoS One 2013;8(04):e61057

18 Kell DB, Pretorius E. On the translocation of bacteria and their lipopolysaccharides between blood and peripheral locations in chronic, inflammatory diseases: the central roles of LPS and LPSinduced cell death. Integr Biol 2015;7(11):1339-1377

19 Morath S, Geyer A, Hartung T. Structure-function relationship of cytokine induction by lipoteichoic acid from Staphylococcus aureus. J Exp Med 2001;193(03):393-397

20 Schröder NW, Morath S, Alexander C, et al. Lipoteichoic acid (LTA) of Streptococcus pneumoniae and Staphylococcus aureus activates immune cells via Toll-like receptor (TLR)-2, lipopolysaccharide-binding protein (LBP), and CD14, whereas TLR-4 and MD-2 are not involved. J Biol Chem 2003;278(18):15587-15594

21 Baik JE, Ryu YH, Han JY, et al. Lipoteichoic acid partially contributes to the inflammatory responses to Enterococcus faecalis. J Endod 2008;34(08):975-982

22 Jeon JH, Kim SK, Baik JE, et al. Lipoteichoic acid of Staphylococcus aureus enhances IL-6 expression in activated human basophils. Comp Immunol Microbiol Infect Dis 2012;35(04):363-374

23 Belum GR, Belum VR, Chaitanya Arudra SK, Reddy BS. The Jarisch-Herxheimer reaction: revisited. Travel Med Infect Dis 2013;11(04):231-237

24 Cheung CM, Chee SP. Jarisch-Herxheimer reaction: paradoxical worsening of tuberculosis chorioretinitis following initiation of antituberculous therapy. Eye (Lond) 2009;23(06):1472-1473

25 Fekade D, Knox K, Hussein K, et al. Prevention of Jarisch-Herxheimer reactions by treatment with antibodies against tumor necrosis factor alpha. N Engl J Med 1996;335(05):311-315

26 Guerrier G, D'Ortenzio E. The Jarisch-Herxheimer reaction in leptospirosis: a systematic review. PLoS One 2013;8(03):e59266

27 Prins JM, van Deventer SJ, Kuijper EJ, Speelman P. Clinical relevance of antibiotic-induced endotoxin release. Antimicrob Agents Chemother 1994;38(06):1211-1218

28 Kirikae T, Nakano M, Morrison DC. Antibiotic-induced endotoxin release from bacteria and its clinical significance. Microbiol Immunol 1997;41(04):285-294

29 Holzheimer RG. Antibiotic induced endotoxin release and clinical sepsis: a review. J Chemother 2001;13(Spec No 1):159-172

30 Lepper PM, Held TK, Schneider EM, Bölke E, Gerlach H, Trautmann M. Clinical implications of antibiotic-induced endotoxin release in septic shock. Intensive Care Med 2002;28(07):824-833

31 Levy MM, Fink MP, Marshall JC, et al; SCCM/ESICM/ACCP/ATS/SIS. 2001 SCCM/ESICM/ACCP/ATS/SIS International Sepsis Definitions Conference. Crit Care Med 2003;31(04):1250-1256

32 Bozza FA, Salluh JI, Japiassu AM, et al. Cytokine profiles as markers of disease severity in sepsis: a multiplex analysis. Crit Care 2007;11(02):R49

33 D'Elia RV, Harrison K, Oyston PC, Lukaszewski RA, Clark GC. Targeting the "cytokine storm" for therapeutic benefit. Clin Vaccine Immunol 2013;20(03):319-327

34 Harrison C. Sepsis: calming the cytokine storm. Nat Rev Drug Discov 2010;9(05):360-361

35 Oldstone MB, Rosen $\mathrm{H}$. Cytokine storm plays a direct role in the morbidity and mortality from influenza virus infection and is chemically treatable with a single sphingosine-1-phosphate agonist molecule. Curr Top Microbiol Immunol 2014;378:129-147

36 Tisoncik JR, Korth MJ, Simmons CP, Farrar J, Martin TR, Katze MG. Into the eye of the cytokine storm. Microbiol Mol Biol Rev 2012; 76(01):16-32

37 Wang $\mathrm{H}, \mathrm{Ma}$ S. The cytokine storm and factors determining the sequence and severity of organ dysfunction in multiple organ dysfunction syndrome. Am J Emerg Med 2008;26(06):711-715

38 Weigand MA, Hörner C, Bardenheuer HJ, Bouchon A. The systemic inflammatory response syndrome. Best Pract Res Clin Anaesthesiol 2004;18(03):455-475 
39 Matsuda N, Hattori Y. Systemic inflammatory response syndrome (SIRS): molecular pathophysiology and gene therapy. J Pharmacol Sci 2006;101(03):189-198

40 Ratzinger F, Schuardt M, Eichbichler K, et al. Utility of sepsis biomarkers and the infection probability score to discriminate sepsis and systemic inflammatory response syndrome in standard care patients. PLoS One 2013;8(12):e82946

41 Reichsoellner M, Raggam RB, Wagner J, Krause R, Hoenigl M. Clinical evaluation of multiple inflammation biomarkers for diagnosis and prognosis for patients with systemic inflammatory response syndrome. J Clin Microbiol 2014;52(11):4063-4066

42 Dunne WM Jr. Laboratory diagnosis of sepsis? No SIRS, not just yet. J Clin Microbiol 2015;53(08):2404-2409

43 Stubljar D, Skvarc M. Effective strategies for diagnosis of systemic inflammatory response syndrome (SIRS) due to bacterial infection in surgical patients. Infect Disord Drug Targets 2015;15(01): 53-56

44 Brown KA, Brain SD, Pearson JD, Edgeworth JD, Lewis SM, Treacher DF. Neutrophils in development of multiple organ failure in sepsis. Lancet 2006;368(9530):157-169

45 Johnson D, Mayers I. Multiple organ dysfunction syndrome: a narrative review. Can J Anaesth 2001;48(05):502-509

46 Gando S. Microvascular thrombosis and multiple organ dysfunction syndrome. Crit Care Med 2010;38(02):S35-S42

47 Laster SM, Wood JG, Gooding LR. Tumor necrosis factor can induce both apoptic and necrotic forms of cell lysis. J Immunol 1988;141(08):2629-2634

48 Sridharan H, Upton JW. Programmed necrosis in microbial pathogenesis. Trends Microbiol 2014;22(04):199-207

49 Singer M. The role of mitochondrial dysfunction in sepsisinduced multi-organ failure. Virulence 2014;5(01):66-72

50 Singer M. Biomarkers in sepsis. Curr Opin Pulm Med 2013; 19(03):305-309

51 Singer M, Deutschman CS, Seymour CW, et al. The Third International Consensus Definitions for Sepsis and Septic Shock (Sepsis-3). JAMA 2016;315(08):801-810

52 Churpek MM, Snyder A, Han X, et al. qSOFA, SIRS, and early warning scores for detecting clinical deterioration in infected patients outside the ICU. Am J Respir Crit Care Med 2017;195 (07):906-911

53 Vincent JL, Moreno R, Takala J, et al. The SOFA (Sepsis-related Organ Failure Assessment) score to describe organ dysfunction/ failure. On behalf of the Working Group on Sepsis-Related Problems of the European Society of Intensive Care Medicine. Intensive Care Med 1996;22(07):707-710

54 Eisele B, Lamy M. Clinical experience with antithrombin III concentrates in critically ill patients with sepsis and multiple organ failure. Semin Thromb Hemost 1998;24(01):71-80

55 Satran R, Almog Y. The coagulopathy of sepsis: pathophysiology and management. Isr Med Assoc J 2003;5(07):516-520

56 Dempfle CE. Coagulopathy of sepsis. Thromb Haemost 2004;91 (02):213-224

57 Kinasewitz GT, Yan SB, Basson B, et al; PROWESS Sepsis Study GroupUniversal changes in biomarkers of coagulation and inflammation occur in patients with severe sepsis, regardless of causative micro-organism [ISRCTN74215569]. Crit Care 2004;8 (02):R82-R90

58 Iba T, Gando S, Murata A, et al; Japanese Association for Acute Medicine Disseminated Intravascular Coagulation Study Group. Predicting the severity of systemic inflammatory response syndrome (SIRS)-associated coagulopathy with hemostatic molecular markers and vascular endothelial injury markers. J Trauma 2007;63(05):1093-1098

59 Ogura H, Gando S, Iba T, et al; Japanese Association for Acute Medicine Disseminated Intravascular Coagulation Study Group. SIRS-associated coagulopathy and organ dysfunction in critically ill patients with thrombocytopenia. Shock 2007;28(04): 411-417
60 Gando S. Role of fibrinolysis in sepsis. Semin Thromb Hemost 2013;39(04):392-399

61 Hoppensteadt D, Tsuruta K, Cunanan J, et al. Thrombin generation mediators and markers in sepsis-associated coagulopathy and their modulation by recombinant thrombomodulin. Clin Appl Thromb Hemost 2014;20(02):129-135

62 Levi M, Schultz M, van der Poll T. Sepsis and thrombosis. Semin Thromb Hemost 2013;39(05):559-566

63 Ostrowski SR, Berg RM, Windeløv NA, et al. Coagulopathy, catecholamines, and biomarkers of endothelial damage in experimental human endotoxemia and in patients with severe sepsis: a prospective study. J Crit Care 2013;28(05):586-596

64 Saracco P, Vitale P, Scolfaro C, Pollio B, Pagliarino M, Timeus F. The coagulopathy in sepsis: significance and implications for treatment. Pediatr Rep 2011;3(04):e30

65 Semeraro N, Ammollo CT, Semeraro F, Colucci M. Coagulopathy of acute sepsis. Semin Thromb Hemost 2015;41(06):650-658

66 Simmons J, Pittet JF. The coagulopathy of acute sepsis. Curr Opin Anaesthesiol 2015;28(02):227-236

67 Muronoi T, Koyama K, Nunomiya S, et al. Immature platelet fraction predicts coagulopathy-related platelet consumption and mortality in patients with sepsis. Thromb Res 2016;144:169-175

68 Tan L, Huang Y, Pan X, et al. Administration of bone marrow stromal cells in sepsis attenuates sepsis-related coagulopathy. Ann Med 2016;48(04):235-245

69 Levi M, van der Poll T. Coagulation and sepsis. Thromb Res 2017; 149:38-44

70 Kell DB. Iron behaving badly: inappropriate iron chelation as a major contributor to the aetiology of vascular and other progressive inflammatory and degenerative diseases. BMC Med Genomics 2009;2:2

71 Kell DB. Towards a unifying, systems biology understanding of large-scale cellular death and destruction caused by poorly liganded iron: Parkinson's, Huntington's, Alzheimer's, prions, bactericides, chemical toxicology and others as examples. Arch Toxicol 2010;84(11):825-889

72 Kell DB, Pretorius E. Serum ferritin is an important inflammatory disease marker, as it is mainly a leakage product from damaged cells. Metallomics 2014;6(04):748-773

73 Pretorius E, Kell DB. Diagnostic morphology: biophysical indicators for iron-driven inflammatory diseases. Integr Biol 2014; 6(05):486-510

74 Kell DB, Pretorius E. The simultaneous occurrence of both hypercoagulability and hypofibrinolysis in blood and serum during systemic inflammation, and the roles of iron and fibrin (ogen). Integr Biol 2015;7(01):24-52

75 Potgieter M, Bester J, Kell DB, Pretorius E. The dormant blood microbiome in chronic, inflammatory diseases. FEMS Microbiol Rev 2015;39(04):567-591

76 Kell DB, Kenny LC. A dormant microbial component in the development of pre-eclampsia. Front Med Obs Gynecol 2016;3:60

77 Kell DB, Pretorius E. Proteins behaving badly. Substoichiometric molecular control and amplification of the initiation and nature of amyloid fibril formation: lessons from and for blood clotting. Prog Biophys Mol Biol 2017;123:16-41

78 Pretorius E, Akeredolu OO, Soma P, Kell DB. Major involvement of bacterial components in rheumatoid arthritis and its accompanying oxidative stress, systemic inflammation and hypercoagulability. Exp Biol Med (Maywood) 2017;242(04):355-373

79 Pretorius E, Bester J, Kell DB. A bacterial component to Alzheimer-type dementia seen via a systems biology approach that links iron dysregulation and inflammagen shedding to disease. J Alzheimers Dis 2016;53(04):1237-1256

80 Pretorius E, Mbotwe S, Bester J, Robinson CJ, Kell DB. Acute induction of anomalous and amyloidogenic blood clotting by molecular amplification of highly substoichiometric levels of bacterial lipopolysaccharide. J R Soc Interface 2016;13(122): 20160539 
81 Ebringer A, Rashid T, Wilson C. Rheumatoid arthritis, Proteus, anti-CCP antibodies and Karl Popper. Autoimmun Rev 2010; 9(04):216-223

82 Ebringer A. Rheumatoid Arthritis and Proteus. London: Springer; 2012

83 Marshall BJ, Warren JR. Unidentified curved bacilli in the stomach of patients with gastritis and peptic ulceration. Lancet 1984; 1(8390):1311-1315

84 Itzhaki RF, Lathe R, Balin BJ, et al. Microbes and Alzheimer's disease. J Alzheimers Dis 2016;51(04):979-984

85 Weisel JW. Fibrinogen and fibrin. Adv Protein Chem 2005; 70:247-299

86 Cilia La Corte AL, Philippou H, Ariëns RA. Role of fibrin structure in thrombosis and vascular disease. Adv Protein Chem Struct Biol 2011;83:75-127

87 Undas A, Ariëns RA. Fibrin clot structure and function: a role in the pathophysiology of arterial and venous thromboembolic diseases. Arterioscler Thromb Vasc Biol 2011;31(12):e88-e99

88 Undas A, Nowakowski T, Cieśla-Dul M, Sadowski J. Abnormal plasma fibrin clot characteristics are associated with worse clinical outcome in patients with peripheral arterial disease and thromboangiitis obliterans. Atherosclerosis 2011;215(02):481-486

89 Wolberg AS. Determinants of fibrin formation, structure, and function. Curr Opin Hematol 2012;19(05):349-356

90 Undas A. Fibrin clot properties and their modulation in thrombotic disorders. Thromb Haemost 2014;112(01):32-42

91 Pretorius E, Vermeulen N, Bester J, Lipinski B, Kell DB. A novel method for assessing the role of iron and its functional chelation in fibrin fibril formation: the use of scanning electron microscopy. Toxicol Mech Methods 2013;23(05):352-359

92 Pretorius E, Bester J, Vermeulen N, Lipinski B, Gericke GS, Kell DB. Profound morphological changes in the erythrocytes and fibrin networks of patients with hemochromatosis or with hyperferritinemia, and their normalization by iron chelators and other agents. PLoS One 2014;9(01):e85271

93 Pretorius E, Bester J, Vermeulen N, et al. Poorly controlled type 2 diabetes is accompanied by significant morphological and ultrastructural changes in both erythrocytes and in thrombin-generated fibrin: implications for diagnostics. Cardiovasc Diabetol 2015; $14: 30$

94 Pretorius E, Windberger UB, Oberholzer HM, Auer RE. Comparative ultrastructure of fibrin networks of a dog after thrombotic ischaemic stroke. Onderstepoort J Vet Res 2010;77(01):E1-E4

95 Pretorius E, Swanepoel AC, Oberholzer HM, van der Spuy WJ, Duim W, Wessels PF. A descriptive investigation of the ultrastructure of fibrin networks in thrombo-embolic ischemic stroke. J Thromb Thrombolysis 2011;31(04):507-513

96 Pretorius E, Steyn H, Engelbrecht M, Swanepoel AC, Oberholzer HM. Differences in fibrin fiber diameters in healthy individuals and thromboembolic ischemic stroke patients. Blood Coagul Fibrinolysis 2011;22(08):696-700

97 Pretorius E, Oberholzer HM, van der Spuy WJ, Swanepoel AC, Soma P. Qualitative scanning electron microscopy analysis of fibrin networks and platelet abnormalities in diabetes. Blood Coagul Fibrinolysis 2011;22(06):463-467

98 Bester J, Soma P, Kell DB, Pretorius E. Viscoelastic and ultrastructural characteristics of whole blood and plasma in Alzheimer-type dementia, and the possible role of bacterial lipopolysaccharides (LPS). Oncotarget 2015;6(34):35284-35303

99 Lipinski B, Pretorius E. Iron-induced fibrin formation may explain vascular pathology in Alzheimer's disease. Folia Neuropathol 2014;52(02):205

100 Lipinski B, Pretorius E. Novel pathway of iron-induced blood coagulation: implications for diabetes mellitus and its complications. Pol Arch Med Wewn 2012;122(03):115-122

101 Lipinski B, Pretorius E. Iron-induced fibrin in cardiovascular disease. Curr Neurovasc Res 2013;10(03):269-274
102 Pretorius E, Vermeulen N, Bester J, Lipinski B. Novel use of scanning electron microscopy for detection of iron-induced morphological changes in human blood. Microsc Res Tech 2013;76(03):268-271

103 Asakura H. Classifying types of disseminated intravascular coagulation: clinical and animal models. J Intensive Care 2014; 2(01):20

104 Duburcq T, Tournoys A, Gnemmi V, et al. Impact of obesity on endotoxin-induced disseminated intravascular coagulation. Shock 2015;44(04):341-347

105 Bick RL. Disseminated intravascular coagulation: a review of etiology, pathophysiology, diagnosis, and management: guidelines for care. Clin Appl Thromb Hemost 2002;8(01):1-31

106 Kaneko T, Wada H. Diagnostic criteria and laboratory tests for disseminated intravascular coagulation. J Clin Exp Hematop 2011;51(02):67-76

107 Levi M. The coagulant response in sepsis and inflammation. Hamostaseologie 2010;30(01):10-12, 14-16

108 Paulus P, Jennewein C, Zacharowski K. Biomarkers of endothelial dysfunction: can they help us deciphering systemic inflammation and sepsis? Biomarkers 2011;16(Suppl 1):S11-S21

109 Khemani RG, Bart RD, Alonzo TA, Hatzakis G, Hallam D, Newth CJ. Disseminated intravascular coagulation score is associated with mortality for children with shock. Intensive Care Med 2009;35 (02):327-333

110 Levi M, van der Poll T. Disseminated intravascular coagulation: a review for the internist. Intern Emerg Med 2013;8(01):23-32

111 Thachil J, Toh $\mathrm{CH}$. Current concepts in the management of disseminated intravascular coagulation. Thromb Res 2012;129 (Suppl 1):S54-S59

112 Wada H, Matsumoto T, Yamashita Y, Hatada T. Disseminated intravascular coagulation: testing and diagnosis. Clin Chim Acta 2014;436:130-134

113 Wu LC, Lin X, Sun H. Tanshinone IIA protects rabbits against LPSinduced disseminated intravascular coagulation (DIC). Acta Pharmacol Sin 2012;33(10):1254-1259

114 Wu Z, Li JN, Bai ZQ Lin X. Antagonism by salvianolic acid B of lipopolysaccharide-induced disseminated intravascular coagulation in rabbits. Clin Exp Pharmacol Physiol 2014;41(07):502-508

115 Yu PX, Zhou QJ, Zhu WW, et al. Effects of quercetin on LPSinduced disseminated intravascular coagulation (DIC) in rabbits. Thromb Res 2013;131(06):e270-e273

116 Nguyen TC, Gushiken F, Correa JI, et al. A recombinant fragment of von Willebrand factor reduces fibrin-rich microthrombi formation in mice with endotoxemia. Thromb Res 2015;135(05): 1025-1030

117 Zeerleder S, Hack CE, Wuillemin WA. Disseminated intravascular coagulation in sepsis. Chest 2005;128(04):2864-2875

118 Gando S, Saitoh D, Ogura H, et al; Japanese Association for Acute Medicine Disseminated Intravascular Coagulation (JAAM DIC) Study Group. Natural history of disseminated intravascular coagulation diagnosed based on the newly established diagnostic criteria for critically ill patients: results of a multicenter, prospective survey. Crit Care Med 2008;36(01):145-150

119 Semeraro N, Ammollo CT, Semeraro F, Colucci M. Sepsis-associated disseminated intravascular coagulation and thromboembolic disease. Mediterr J Hematol Infect Dis 2010;2(03): e2010024

120 Gando S, Meziani F, Levi M. What's new in the diagnostic criteria of disseminated intravascular coagulation? Intensive Care Med 2016;42(06):1062-1064

121 Cunningham FG, Nelson DB. Disseminated intravascular coagulation syndromes in obstetrics. Obstet Gynecol 2015;126(05): 999-1011

122 Anfinsen CB, Haber E, Sela M, White FH Jr. The kinetics of formation of native ribonuclease during oxidation of the reduced polypeptide chain. Proc Natl Acad Sci U S A 1961;47:1309-1314 
123 Anfinsen CB. Principles that govern the folding of protein chains. Science 1973;181(4096):223-230

124 Cohen FE, Prusiner SB. Pathologic conformations of prion proteins. Annu Rev Biochem 1998;67:793-819

125 Harrison PM, Chan HS, Prusiner SB, Cohen FE. Thermodynamics of model prions and its implications for the problem of prion protein folding. J Mol Biol 1999;286(02):593-606

126 Prusiner SB. Prions. Proc Natl Acad Sci U S A 1998;95(23): 13363-13383

127 Aguzzi A. Prion diseases of humans and farm animals: epidemiology, genetics, and pathogenesis. J Neurochem 2006;97(06): 1726-1739

128 Aguzzi A, Sigurdson C, Heikenwaelder M. Molecular mechanisms of prion pathogenesis. Annu Rev Pathol 2008;3:11-40

129 Aguzzi A, Lakkaraju AK. Cell biology of prions and prionoids: a status report. Trends Cell Biol 2016;26(01):40-51

130 Colby DW, Prusiner SB. Prions. Cold Spring Harb Perspect Biol 2011;3(01):a006833

131 Prusiner SB. Biology and genetics of prions causing neurodegeneration. Annu Rev Genet 2013;47:601-623

132 Collinge J, Clarke AR. A general model of prion strains and their pathogenicity. Science 2007;318(5852):930-936

133 Aguzzi A, Calella AM. Prions: protein aggregation and infectious diseases. Physiol Rev 2009;89(04):1105-1152

134 Ashe KH, Aguzzi A. Prions, prionoids and pathogenic proteins in Alzheimer disease. Prion 2013;7(01):55-59

135 Watts JC, Condello C, Stöhr J, et al. Serial propagation of distinct strains of $A \beta$ prions from Alzheimer's disease patients. Proc Natl Acad Sci U S A 2014;111(28):10323-10328

136 Woerman AL, Stöhr J, Aoyagi A, et al. Propagation of prions causing synucleinopathies in cultured cells. Proc Natl Acad Sci U S A 2015;112(35):E4949-E4958

137 Benson MD, Liepnieks J, Uemichi T, Wheeler G, Correa R. Hereditary renal amyloidosis associated with a mutant fibrinogen alpha-chain. Nat Genet 1993;3(03):252-255

138 Hamidi Asl L, Liepnieks JJ, Uemichi T, et al. Renal amyloidosis with a frame shift mutation in fibrinogen aalpha-chain gene producing a novel amyloid protein. Blood 1997;90(12):4799-4805

139 Serpell LC, Benson M, Liepnieks JJ, Fraser PE. Structural analyses of fibrinogen amyloid fibrils. Amyloid 2007;14(03):199-203

140 Gillmore JD, Lachmann HJ, Rowczenio D, et al. Diagnosis, pathogenesis, treatment, and prognosis of hereditary fibrinogen $\mathrm{A}$ alpha-chain amyloidosis. J Am Soc Nephrol 2009;20(02): 444-451

141 Picken MM. Fibrinogen amyloidosis: the clot thickens!. Blood 2010;115(15):2985-2986

142 Stangou AJ, Banner NR, Hendry BM, et al. Hereditary fibrinogen A alpha-chain amyloidosis: phenotypic characterization of a systemic disease and the role of liver transplantation. Blood 2010; 115(15):2998-3007

143 Haidinger M, Werzowa J, Kain R, et al. Hereditary amyloidosis caused by R554L fibrinogen A $\alpha$-chain mutation in a Spanish family and review of the literature. Amyloid 2013;20(02):72-79

144 Zhmurov A, Brown AE, Litvinov RI, Dima RI, Weisel JW, Barsegov V. Mechanism of fibrin(ogen) forced unfolding. Structure 2011; 19(11):1615-1624

145 Litvinov RI, Faizullin DA, Zuev YF, Weisel JW. The $\alpha$-helix to $\beta$-sheet transition in stretched and compressed hydrated fibrin clots. Biophys J 2012;103(05):1020-1027

146 Zhmurov A, Kononova O, Litvinov RI, Dima RI, Barsegov V, Weisel JW. Mechanical transition from $\alpha$-helical coiled coils to $\beta$-sheets in fibrin(ogen). J Am Chem Soc 2012;134(50):20396-20402

147 Kreplak L, Doucet J, Dumas P, Briki F. New aspects of the alphahelix to beta-sheet transition in stretched hard alpha-keratin fibers. Biophys J 2004;87(01):640-647

148 Guthold M, Liu W, Sparks EA, et al. A comparison of the mechanical and structural properties of fibrin fibers with other protein fibers. Cell Biochem Biophys 2007;49(03):165-181
149 Liu W, Carlisle CR, Sparks EA, Guthold M. The mechanical properties of single fibrin fibers. J Thromb Haemost 2010; 8(05):1030-1036

150 Miserez A, Guerette PA. Phase transition-induced elasticity of $\alpha$ helical bioelastomeric fibres and networks. Chem Soc Rev 2013; 42(05):1973-1995

151 Kell DB, Pretorius E. Substoichiometric molecular control and amplification of the initiation and nature of amyloid fibril formation: lessons from and for blood clotting. bioRxiv preprint. bioRxiv 2016:054734

152 Weisel JW. Structure of fibrin: impact on clot stability. J Thromb Haemost 2007;5(Suppl 1):116-124

153 Wolberg AS. Thrombin generation and fibrin clot structure. Blood Rev 2007;21(03):131-142

154 Biancalana M, Makabe K, Koide A, Koide S. Molecular mechanism of thioflavin-T binding to the surface of beta-rich peptide selfassemblies. J Mol Biol 2009;385(04):1052-1063

155 Biancalana M, Koide S. Molecular mechanism of Thioflavin-T binding to amyloid fibrils. Biochim Biophys Acta 2010;1804(07): 1405-1412

156 Groenning M. Binding mode of Thioflavin T and other molecular probes in the context of amyloid fibrils-current status. J Chem Biol 2010;3(01):1-18

157 Kuznetsova IM, Sulatskaya AI, Uversky VN, Turoverov KK. Analyzing thioflavin $\mathrm{T}$ binding to amyloid fibrils by an equilibrium microdialysis-based technique. PLoS One 2012;7(02):e30724

158 Kuznetsova IM, Sulatskaya AI, Uversky VN, Turoverov KK. A new trend in the experimental methodology for the analysis of the thioflavin $\mathrm{T}$ binding to amyloid fibrils. Mol Neurobiol 2012; 45(03):488-498

159 Kuznetsova IM, Sulatskaya AI, Maskevich AA, Uversky VN, Turoverov KK. High fluorescence anisotropy of thioflavin $T$ in aqueous solution resulting from its molecular rotor nature. Anal Chem 2016;88(01):718-724

160 Lindberg DJ, Wranne MS, Gilbert Gatty M, Westerlund F, Esbjörner EK. Steady-state and time-resolved Thioflavin-T fluorescence can report on morphological differences in amyloid fibrils formed by $A \beta(1-40)$ and $A \beta(1-42)$. Biochem Biophys Res Commun 2015;458(02):418-423

161 Sulatskaya AI, Kuznetsova IM, Turoverov KK. Interaction of thioflavin $\mathrm{T}$ with amyloid fibrils: fluorescence quantum yield of bound dye. J Phys Chem B 2012;116(08):2538-2544

162 Younan ND, Viles JH. A comparison of three fluorophores for the detection of amyloid fibers and prefibrillar oligomeric assemblies. ThT (thioflavin T); ANS (1-anilinonaphthalene-8-sulfonic acid); and bisANS (4,4'-dianilino-1,1'-binaphthyl-5,5'-disulfonic acid). Biochemistry 2015;54(28):4297-4306

163 Zhang X, Ran C. Dual functional small molecule probes as fluorophore and ligand for misfolding proteins. Curr Org Chem 2013;17(06):6

164 Ahn HJ, Zamolodchikov D, Cortes-Canteli M, Norris EH, Glickman JF, Strickland S. Alzheimer's disease peptide beta-amyloid interacts with fibrinogen and induces its oligomerization. Proc Natl Acad Sci U S A 2010;107(50):21812-21817

165 Ahn HJ, Glickman JF, Poon KL, et al. A novel Aß-fibrinogen interaction inhibitor rescues altered thrombosis and cognitive decline in Alzheimer's disease mice. J Exp Med 2014;211(06):1049-1062

166 Cortes-Canteli M, Strickland S. Fibrinogen, a possible key player in Alzheimer's disease. J Thromb Haemost 2009;7(Suppl 1):146-150

167 Cortes-Canteli M, Zamolodchikov D, Ahn HJ, Strickland S, Norris EH. Fibrinogen and altered hemostasis in Alzheimer's disease. J Alzheimers Dis 2012;32(03):599-608

168 Cortes-Canteli M, Mattei L, Richards AT, Norris EH, Strickland S. Fibrin deposited in the Alzheimer's disease brain promotes neuronal degeneration. Neurobiol Aging 2015;36(02):608-617

169 Paul J, Strickland S, Melchor JP. Fibrin deposition accelerates neurovascular damage and neuroinflammation in mouse models of Alzheimer's disease. J Exp Med 2007;204(08):1999-2008 
170 Zamolodchikov D, Strickland S. A possible new role for $A B$ in vascular and inflammatory dysfunction in Alzheimer's disease. Thromb Res 2016;141(Suppl 2):S59-S61

171 Cortes-Canteli M, Paul J, Norris EH, et al. Fibrinogen and betaamyloid association alters thrombosis and fibrinolysis: a possible contributing factor to Alzheimer's disease. Neuron 2010; 66(05):695-709

172 Zamolodchikov D, Strickland S. A $\beta$ delays fibrin clot lysis by altering fibrin structure and attenuating plasminogen binding to fibrin. Blood 2012;119(14):3342-3351

173 Zamolodchikov D, Berk-Rauch HE, Oren DA, et al. Biochemical and structural analysis of the interaction between $\beta$-amyloid and fibrinogen. Blood 2016;128(08):1144-1151

174 Akassoglou K, Adams RA, Bauer J, et al. Fibrin depletion decreases inflammation and delays the onset of demyelination in a tumor necrosis factor transgenic mouse model for multiple sclerosis. Proc Natl Acad Sci U S A 2004;101(17): 6698-6703

175 Levi M, van der Poll T, Büller HR. Bidirectional relation between inflammation and coagulation. Circulation 2004;109(22): 2698-2704

176 Flick MJ, LaJeunesse CM, Talmage KE, et al. Fibrin(ogen) exacerbates inflammatory joint disease through a mechanism linked to the integrin alphaMbeta2 binding motif. J Clin Invest 2007; 117(11):3224-3235

177 Jennewein C, Tran N, Paulus P, Ellinghaus P, Eble JA, Zacharowski K. Novel aspects of fibrin(ogen) fragments during inflammation. Mol Med 2011;17(5-6):568-573

178 Jennewein C, Paulus P, Zacharowski K. Linking inflammation and coagulation: novel drug targets to treat organ ischemia. Curr Opin Anaesthesiol 2011;24(04):375-380

179 Schuliga M. The inflammatory actions of coagulant and fibrinolytic proteases in disease. Mediators Inflamm 2015; 2015:437695

180 Cahill CM, Lahiri DK, Huang X, Rogers JT. Amyloid precursor protein and alpha synuclein translation, implications for iron and inflammation in neurodegenerative diseases. Biochim Biophys Acta 2009;1790(07):615-628

181 Hirohata M, Ono K, Yamada M. Non-steroidal anti-inflammatory drugs as anti-amyloidogenic compounds. Curr Pharm Des 2008; 14(30):3280-3294

182 Minter MR, Taylor JM, Crack PJ. The contribution of neuroinflammation to amyloid toxicity in Alzheimer's disease. J Neurochem 2016;136(03):457-474

183 Spaulding CN, Dodson KW, Chapman MR, Hultgren SJ. Fueling the fire with fibers: bacterial amyloids promote inflammatory disorders. Cell Host Microbe 2015;18(01):1-2

184 Lin IH, Miller DS, Bertics PJ, Murphy CJ, de Pablo JJ, Abbott NL. Endotoxin-induced structural transformations in liquid crystalline droplets. Science 2011;332(6035):1297-1300

185 Miller DS, Abbott NL. Influence of droplet size, pH and ionic strength on endotoxin-triggered ordering transitions in liquid crystalline droplets. Soft Matter 2013;9(02):374-382

186 Carter MC, Miller DS, Jennings J, et al. Synthetic mimics of bacterial lipid A trigger optical transitions in liquid crystal microdroplets at ultralow picogram-per-milliliter concentrations. Langmuir 2015;31(47):12850-12855

187 Singh N, Haldar S, Tripathi AK, McElwee MK, Horback K, Beserra A. Iron in neurodegenerative disorders of protein misfolding: a case of prion disorders and Parkinson's disease. Antioxid Redox Signal 2014;21(03):471-484

188 Singh N. The role of iron in prion disease and other neurodegenerative diseases. PLoS Pathog 2014;10(09):e1004335

189 Singh N, Asthana A, Baksi S, et al. The prion-ZIP connection: from cousins to partners in iron uptake. Prion 2015;9(06):420-428

190 Ahmed M, Davis J, Aucoin D, et al. Structural conversion of neurotoxic amyloid-beta(1-42) oligomers to fibrils. Nat Struct Mol Biol 2010;17(05):561-567
191 Hefti F, Goure WF, Jerecic J, Iverson KS, Walicke PA, Krafft GA. The case for soluble $A \beta$ oligomers as a drug target in Alzheimer's disease. Trends Pharmacol Sci 2013;34(05):261-266

192 Kayed R, Lasagna-Reeves CA. Molecular mechanisms of amyloid oligomers toxicity. J Alzheimers Dis 2013;33(Suppl 1):S67-S78

193 Liu B, Moloney A, Meehan S, et al. Iron promotes the toxicity of amyloid beta peptide by impeding its ordered aggregation. J Biol Chem 2011;286(06):4248-4256

194 Meyer-Luehmann M, Spires-Jones TL, Prada C, et al. Rapid appearance and local toxicity of amyloid-beta plaques in a mouse model of Alzheimer's disease. Nature 2008;451(7179):720-724

195 Miranda S, Opazo C, Larrondo LF, et al. The role of oxidative stress in the toxicity induced by amyloid beta-peptide in Alzheimer's disease. Prog Neurobiol 2000;62(06):633-648

196 Rival T, Page RM, Chandraratna DS, et al. Fenton chemistry and oxidative stress mediate the toxicity of the beta-amyloid peptide in a Drosophila model of Alzheimer's disease. Eur J Neurosci 2009;29(07):1335-1347

197 Sengupta U, Nilson AN, Kayed R. The role of amyloid- $\beta$ oligomers in toxicity, propagation, and immunotherapy. EBioMedicine 2016;6:42-49

198 Uversky VN. Mysterious oligomerization of the amyloidogenic proteins. FEBS J 2010;277(14):2940-2953

199 Janson J, Ashley RH, Harrison D, McIntyre S, Butler PC. The mechanism of islet amyloid polypeptide toxicity is membrane disruption by intermediate-sized toxic amyloid particles. Diabetes 1999;48(03):491-498

200 Bucciantini M, Giannoni E, Chiti F, et al. Inherent toxicity of aggregates implies a common mechanism for protein misfolding diseases. Nature 2002;416(6880):507-511

201 Kayed R, Head E, Thompson JL, et al. Common structure of soluble amyloid oligomers implies common mechanism of pathogenesis. Science 2003;300(5618):486-489

202 Baglioni S, Casamenti F, Bucciantini M, et al. Prefibrillar amyloid aggregates could be generic toxins in higher organisms. J Neurosci 2006;26(31):8160-8167

203 Glabe CG. Common mechanisms of amyloid oligomer pathogenesis in degenerative disease. Neurobiol Aging 2006;27(04):570-575

204 Konarkowska B, Aitken JF, Kistler J, Zhang S, Cooper GJ. The aggregation potential of human amylin determines its cytotoxicity towards islet beta-cells. FEBS J 2006;273(15):3614-3624

205 Meier JJ, Kayed R, Lin CY, et al. Inhibition of human IAPP fibril formation does not prevent beta-cell death: evidence for distinct actions of oligomers and fibrils of human IAPP. Am J Physiol Endocrinol Metab 2006;291(06):E1317-E1324

206 Haass C, Selkoe DJ. Soluble protein oligomers in neurodegeneration: lessons from the Alzheimer's amyloid beta-peptide. Nat Rev Mol Cell Biol 2007;8(02):101-112

207 Xue WF, Hellewell AL, Gosal WS, Homans SW, Hewitt EW, Radford SE. Fibril fragmentation enhances amyloid cytotoxicity. J Biol Chem 2009;284(49):34272-34282

208 Aitken JF, Loomes KM, Scott DW, et al. Tetracycline treatment retards the onset and slows the progression of diabetes in human amylin/islet amyloid polypeptide transgenic mice. Diabetes 2010;59(01):161-171

209 Xue WF, Hellewell AL, Hewitt EW, Radford SE. Fibril fragmentation in amyloid assembly and cytotoxicity: when size matters. Prion 2010;4(01):20-25

210 Fändrich M. Oligomeric intermediates in amyloid formation: structure determination and mechanisms of toxicity. J Mol Biol 2012;421(4-5):427-440

211 Göransson AL, Nilsson KPR, Kågedal K, Brorsson AC. Identification of distinct physiochemical properties of toxic prefibrillar species formed by $A \beta$ peptide variants. Biochem Biophys Res Commun 2012;420(04):895-900

212 Stefani M. Structural features and cytotoxicity of amyloid oligomers: implications in Alzheimer's disease and other diseases with amyloid deposits. Prog Neurobiol 2012;99(03):226-245 
213 Dobson CM. The amyloid phenomenon and its significance. . In: Otzen DE, ed. Amyloid Fibrils and Prefibrillar Aggregates: Molecular and Biological Properties. Weinheim, Germany: Wiley-VCH; 2013:1-19

214 Pillay K, Govender P. Amylin uncovered: a review on the polypeptide responsible for type II diabetes. BioMed Res Int 2013; 2013:826706

215 Trikha S, Jeremic AM. Distinct internalization pathways of human amylin monomers and its cytotoxic oligomers in pancreatic cells. PLoS One 2013;8(09):e73080

216 Zhang S, Liu H, Chuang CL, et al. The pathogenic mechanism of diabetes varies with the degree of overexpression and oligomerization of human amylin in the pancreatic islet $\beta$ cells. FASEB J 2014;28(12):5083-5096

217 Holm NK, Jespersen SK, Thomassen LV, et al. Aggregation and fibrillation of bovine serum albumin. Biochim Biophys Acta 2007;1774(09):1128-1138

218 Barton CH, Vaziri ND, Gordon S, Tilles S. Renal pathology in endstage renal disease associated with paraplegia. Paraplegia 1984; 22(01):31-41

219 Jadoul M, Garbar C, Noël H, et al. Histological prevalence of beta 2-microglobulin amyloidosis in hemodialysis: a prospective post-mortem study. Kidney Int 1997;51(06):1928-1932

220 Ben-Dov IZ, Pizov G, Ben-Chetrit E, Rubinger D, Or R. Fatal nephrotic syndrome complicating allogeneic stem cell transplantation: a case report. Nephrol Dial Transplant 2009;24(09): 2946-2949

221 Lachmann HJ. Secondary AA amyloidosis. Contemp Hematol 2010:179-189

222 Lucas S. The Autopsy Pathology of Sepsis-Related Death, Severe Sepsis and Septic Shock - Understanding a Serious Killer. In: Fernandez R, ed. Rijeka: InTech Open; 2012. Available at: http:/ www.intechopen.com/books/severe-sepsis-and-septic-shock-understanding-a-serious-killer/theautopsy-pathology-of-sepsis-andseptic-shock. Accessed July 27, 2017

223 Díez R, Madero M, Gamba G, Soriano J, Soto V. Renal AA amyloidosis in patients with type 2 diabetes mellitus. Nephron Extra 2014;4(02):119-126

224 Gross PA. Hypotension and mortality in septic shock: the "golden hour." Crit Care Med 2006;34(06):1819-1820

225 Kumar A, Roberts D, Wood KE, et al. Duration of hypotension before initiation of effective antimicrobial therapy is the critical determinant of survival in human septic shock. Crit Care Med 2006;34(06):1589-1596

226 Bagshaw SM, Lapinsky S, Dial S, et al; Cooperative Antimicrobial Therapy of Septic Shock (CATSS) Database Research Group. Acute kidney injury in septic shock: clinical outcomes and impact of duration of hypotension prior to initiation of antimicrobial therapy. Intensive Care Med 2009;35(05):871-881

227 Holler JG, Bech CN, Henriksen DP, Mikkelsen S, Pedersen C, Lassen AT. Nontraumatic hypotension and shock in the emergency department and the prehospital setting, prevalence, etiology, and mortality: a systematic review. PLoS One 2015;10(03): e0119331

228 Gamper G, Havel C, Arrich J, et al. Vasopressors for hypotensive shock. Cochrane Database Syst Rev 2016;2:CD003709

229 Calabrese EJ. Hormesis and medicine. Br J Clin Pharmacol 2008; 66(05):594-617

230 Cox LA Jr. Hormesis without cell killing. Risk Anal 2009;29(03): 393-400

231 Mattson MP. Hormesis and disease resistance: activation of cellular stress response pathways. Hum Exp Toxicol 2008; 27(02):155-162

232 Wang D, Wei J, Hsu K, et al. Effects of nitric oxide synthase inhibitors on systemic hypotension, cytokines and inducible nitric oxide synthase expression and lung injury following endotoxin administration in rats. J Biomed Sci 1999;6(01):28-35
233 Harada N, Okajima K, Isobe H, Uchiba M. Antithrombin reduces endotoxin-induced hypotension by enhancing pulmonary sensory neuron activation in rats. Thromb Haemost 2006;95(06):1011-1018

234 Cayla C, Todiras M, Iliescu R, et al. Mice deficient for both kinin receptors are normotensive and protected from endotoxin-induced hypotension. FASEB J 2007;21(08):1689-1698

235 Uchiba M, Okajima K, Murakami K, Okabe H, Takatsuki K. Attenuation of endotoxin-induced pulmonary vascular injury by antithrombin III. Am J Physiol 1996;270(6 Pt 1):L921-L930

236 Fourrier F, Jourdain M, Tournoys A. Clinical trial results with antithrombin III in sepsis. Crit Care Med 2000;28(09):S38-S43

237 Hoffmann JN, Vollmar B, Römisch J, Inthorn D, Schildberg FW, Menger MD. Antithrombin effects on endotoxin-induced microcirculatory disorders are mediated mainly by its interaction with microvascular endothelium. Crit Care Med 2002;30(01):218-225

238 Isobe $\mathrm{H}$, Okajima K, Uchiba M, Harada N, Okabe H. Antithrombin prevents endotoxin-induced hypotension by inhibiting the induction of nitric oxide synthase in rats. Blood 2002;99(05): $1638-1645$

239 Iba T, Kidokoro A. High-dose antithrombin therapy for sepsis: mechanisms of action. Shock 2002;18(05):389-394

240 Ostermann H. Antithrombin III in Sepsis. New evidences and open questions. Minerva Anestesiol 2002;68(05):445-448

241 Iba T, Kidokoro A, Fukunaga M, et al. Antithrombin ameliorates endotoxin-induced organ dysfunction more efficiently when combined with danaparoid sodium than with unfractionated heparin. Intensive Care Med 2005;31(08):1101-1108

242 Wiedermann CJ. Clinical review: molecular mechanisms underlying the role of antithrombin in sepsis. Crit Care 2006;10(01):209

243 Komura H, Uchiba M, Mizuochi Y, et al. Antithrombin inhibits lipopolysaccharide-induced tumor necrosis factor-alpha production by monocytes in vitro through inhibition of Egr-1 expression. J Thromb Haemost 2008;6(03):499-507

244 Levi M, Schouten M, van der Poll T. Sepsis, coagulation, and antithrombin: old lessons and new insights. Semin Thromb Hemost 2008;34(08):742-746

245 Iba T, Saitoh D. Efficacy of antithrombin in preclinical and clinical applications for sepsis-associated disseminated intravascular coagulation. J Intensive Care 2014;2(01):66

246 Tagami T, Matsui $H$, Horiguchi $H$, Fushimi $K$, Yasunaga $H$. Antithrombin and mortality in severe pneumonia patients with sepsis-associated disseminated intravascular coagulation: an observational nationwide study. J Thromb Haemost 2014; 12(09):1470-1479

247 Iba T, Thachil J. Present and future of anticoagulant therapy using antithrombin and thrombomodulin for sepsis-associated disseminated intravascular coagulation: a perspective from Japan. Int J Hematol 2016;103(03):253-261

248 Helmerhorst EJ, Maaskant JJ, Appelmelk BJ. Anti-lipid A monoclonal antibody centoxin (HA-1A) binds to a wide variety of hydrophobic ligands. Infect Immun 1998;66(02):870-873

249 Marks L. The birth pangs of monoclonal antibody therapeutics: the failure and legacy of Centoxin. MAbs 2012;4(03):403-412

250 Murphy ST, Bellamy MC. The quest for the magic bullet: Centoxin, Drotrecogin Alfa and lessons not learned. Trends Anaesth Crit Care 2013;3:316-319

251 Martí-Carvajal AJ, Solà I, Gluud C, Lathyris D, Cardona AF. Human recombinant protein $C$ for severe sepsis and septic shock in adult and paediatric patients. Cochrane Database Syst Rev 2012; 12:CD004388

252 Lai PS, Matteau A, Iddriss A, Hawes JC, Ranieri V, Thompson BT. An updated meta-analysis to understand the variable efficacy of drotrecogin alfa (activated) in severe sepsis and septic shock. Minerva Anestesiol 2013;79(01):33-43

253 Nadel S, Goldstein B, Williams MD, et al; REsearching severe Sepsis and Organ dysfunction in children: a gLobal perspective (RESOLVE) study group. Drotrecogin alfa (activated) in children 
with severe sepsis: a multicentre phase III randomised controlled trial. Lancet 2007;369(9564):836-843

254 Minnich DJ, Moldawer LL. Anti-cytokine and anti-inflammatory therapies for the treatment of severe sepsis: progress and pitfalls. Proc Nutr Soc 2004;63(03):437-441

255 Aziz M, Jacob A, Yang WL, Matsuda A, Wang P. Current trends in inflammatory and immunomodulatory mediators in sepsis. J Leukoc Biol 2013;93(03):329-342

256 Kell DB. Finding novel pharmaceuticals in the systems biology era using multiple effective drug targets, phenotypic screening and knowledge of transporters: where drug discovery went wrong and how to fix it. FEBS J 2013;280(23): 5957-5980

257 Weinberg ED. Iron withholding: a defense against infection and neoplasia. Physiol Rev 1984;64(01):65-102

258 Xia Y, Farah N, Maxan A, Zhou J, Lehmann C. Therapeutic iron restriction in sepsis. Med Hypotheses 2016;89:37-39

259 Chapin JC, Hajjar KA. Fibrinolysis and the control of blood coagulation. Blood Rev 2015;29(01):17-24

260 Cornet AD, Smit EG, Beishuizen A, Groeneveld AB. The role of heparin and allied compounds in the treatment of sepsis. Thromb Haemost 2007;98(03):579-586

261 Wang C, Chi C, Guo L, et al. Heparin therapy reduces 28-day mortality in adult severe sepsis patients: a systematic review and meta-analysis. Crit Care 2014;18(05):563

262 Zarychanski R, Abou-Setta AM, Kanji S, et al; Canadian Critical Care Trials Group. The efficacy and safety of heparin in patients with sepsis: a systematic review and metaanalysis. Crit Care Med 2015;43(03):511-518

263 van Roessel S, van der Laan AM, de Pont A-CJM. What is the best heparin to treat sepsis with? Crit Care Med 2015;43(06): e212-e213

264 Okamoto K, Tamura T, Sawatsubashi Y. Sepsis and disseminated intravascular coagulation. J Intensive Care 2016;4:23

265 Rosenberg VA, Buhimschi IA, Lockwood CJ, et al. Heparin elevates circulating soluble fms-like tyrosine kinase- 1 immunoreactivity in pregnant women receiving anticoagulation therapy. Circulation 2011;124(23):2543-2553

266 Iba T, Hashiguchi N, Nagaoka I, Tabe Y, Kadota K, Sato K. Heparins attenuated histone-mediated cytotoxicity in vitro and improved the survival in a rat model of histone-induced organ dysfunction. Intensive Care Med Exp 2015;3(01):36

267 Wiedermann CJ, Kaneider NC. A systematic review of antithrombin concentrate use in patients with disseminated intravascular coagulation of severe sepsis. Blood Coagul Fibrinolysis 2006;17(07):521-526

268 Iba T, Saitoh D, Gando S, Thachil J. The usefulness of antithrombin activity monitoring during antithrombin supplementation in patients with sepsis-associated disseminated intravascular coagulation. Thromb Res 2015;135(05):897-901

269 Warren BL, Eid A, Singer P, et al; KyberSept Trial Study Group. Caring for the critically ill patient. High-dose antithrombin III in severe sepsis: a randomized controlled trial. JAMA 2001; 286(15):1869-1878

270 Iba T, Yamada A, Hashiguchi N, Nagaoka I. New therapeutic options for patients with sepsis and disseminated intravascular coagulation. Pol Arch Med Wewn 2014;124(06):321-328

271 Yamakawa K, Umemura Y, Hayakawa M, et al; Japan Septic Disseminated Intravascular Coagulation (J-Septic DIC) study group. Benefit profile of anticoagulant therapy in sepsis: a nationwide multicentre registry in Japan. Crit Care 2016; 20(01):229

272 Chien JY, Jerng JS, Yu CJ, Yang PC. Low serum level of high-density lipoprotein cholesterol is a poor prognostic factor for severe sepsis. Crit Care Med 2005;33(08):1688-1693

273 Levels JHM, Geurts P, Karlsson H, et al. High-density lipoprotein proteome dynamics in human endotoxemia. Proteome Sci 2011; $9(01): 34$
274 Catapano AL, Pirillo A, Bonacina F, Norata GD. HDL in innate and adaptive immunity. Cardiovasc Res 2014;103(03):372-383

275 Bandeali S, Farmer J. High-density lipoprotein and atherosclerosis: the role of antioxidant activity. Curr Atheroscler Rep 2012; 14(02):101-107

276 Tabet F, Rye KA. High-density lipoproteins, inflammation and oxidative stress. Clin Sci (Lond) 2009;116(02):87-98

277 Guo L, Ai J, Zheng Z, et al. High density lipoprotein protects against polymicrobe-induced sepsis in mice. J Biol Chem 2013; 288(25):17947-17953

278 Contreras-Duarte S, Varas P, Awad F, Busso D, Rigotti A. Protective role of high density lipoproteins in sepsis: basic issues and clinical implications . [in Spanish]. Rev Chilena Infectol 2014; 31(01):34-43

279 Pirillo A, Catapano AL, Norata GD. HDL in infectious diseases and sepsis. Handb Exp Pharmacol 2015;224:483-508

280 Almog Y, Shefer A, Novack V, et al. Prior statin therapy is associated with a decreased rate of severe sepsis. Circulation 2004;110(07):880-885

281 Dobesh PP, Olsen KM. Statins role in the prevention and treatment of sepsis. Pharmacol Res 2014;88:31-40

282 Harvey M, Cave G. Co-administration of phospholipid emulsion with first dose bacteriocidal antibiotic may retard progression of the sepsis response in gram negative septicaemia. Med Hypotheses 2014;83(05):563-565

283 Saito H, Maruyama I, Shimazaki S, et al. Efficacy and safety of recombinant human soluble thrombomodulin (ART-123) in disseminated intravascular coagulation: results of a phase III, randomized, double-blind clinical trial. J Thromb Haemost 2007; 5(01):31-41

284 Levi M, Van Der Poll T. Thrombomodulin in sepsis. Minerva Anestesiol 2013;79(03):294-298

285 Mimuro J, Takahashi H, Kitajima I, et al. Impact of recombinant soluble thrombomodulin (thrombomodulin alfa) on disseminated intravascular coagulation. Thromb Res 2013;131(05):436-443

286 Vincent JL, Ramesh MK, Ernest D, et al. A randomized, doubleblind, placebo-controlled, Phase $2 \mathrm{~b}$ study to evaluate the safety and efficacy of recombinant human soluble thrombomodulin, ART-123, in patients with sepsis and suspected disseminated intravascular coagulation. Crit Care Med 2013;41(09):2069-2079

287 Eguchi Y, Gando S, Ishikura H, et al. Post-marketing surveillance data of thrombomodulin alfa: sub-analysis in patients with sepsis-induced disseminated intravascular coagulation. J Intensive Care 2014;2(01):30

288 Shirahata A, Mimuro J, Takahashi H, et al. Recombinant soluble human thrombomodulin (thrombomodulin alfa) in the treatment of neonatal disseminated intravascular coagulation. Eur J Pediatr 2014;173(03):303-311

289 Yamakawa K, Aihara M, Ogura H, Yuhara H, Hamasaki T, Shimazu T. Recombinant human soluble thrombomodulin in severe sepsis: a systematic review and meta-analysis. J Thromb Haemost 2015;13(04):508-519

290 Yoshimura J, Yamakawa K, Ogura H, et al. Benefit profile of recombinant human soluble thrombomodulin in sepsis-induced disseminated intravascular coagulation: a multicenter propensity score analysis. Crit Care 2015;19:78

291 Levi M. Recombinant soluble thrombomodulin: coagulation takes another chance to reduce sepsis mortality. J Thromb Haemost 2015;13(04):505-507

292 Hayakawa M, Yamakawa K, Saito S, et al; Japan Septic Disseminated Intravascular Coagulation (JSEPTIC DIC) study group. Recombinant human soluble thrombomodulin and mortality in sepsis-induced disseminated intravascular coagulation. A multicentre retrospective study. Thromb Haemost 2016;115(06):1157-1166

293 Iba T, Gando S, Saitoh D, Wada H, Di Nisio M, Thachil J. Antithrombin supplementation and risk of bleeding in patients with sepsis-associated disseminated intravascular coagulation. Thromb Res 2016;145:46-50 
294 Wada H, Thachil J, Di Nisio M, Kurosawa S, Gando S, Toh $\mathrm{CH}$; Scientific and Standardization Committee on DIC of the International Society on Thrombosis and Haemostasis. Harmonized guidance for disseminated intravascular coagulation from the International Society on Thrombosis and Haemostasis and the current status of anticoagulant therapy in Japan: a rebuttal. J Thromb Haemost 2013;11(11):2078-2079

295 Iba T, Thachil J. Is antithrombin III for sepsis-associated disseminated intravascular coagulation really ineffective? Intensive Care Med 2016;42(07):1193-1194

296 Dellinger RP, Levy MM, Rhodes A, et al; Surviving Sepsis Campaign Guidelines Committee including The Pediatric Subgroup. Surviving Sepsis Campaign: international guidelines for management of severe sepsis and septic shock, 2012. Intensive Care Med 2013;39(02):165-228

297 Iba T, Gando S, Thachil J. Anticoagulant therapy for sepsisassociated disseminated intravascular coagulation: the view from Japan. J Thromb Haemost 2014;12(07):1010-1019

298 Oda S, Aibiki M, Ikeda T, et al; Sepsis Registry Committee of The Japanese Society of Intensive Care Medicine. The Japanese guidelines for the management of sepsis. J Intensive Care 2014;2(01):55

299 Wada H, Asakura H, Okamoto K, et al; Japanese Society of Thrombosis Hemostasis/DIC subcommittee. Expert consensus for the treatment of disseminated intravascular coagulation in Japan. Thromb Res 2010;125(01):6-11

300 Wada H, Okamoto K, Iba T, et al; Japanese Society of Thrombosis Hemostasis/DIC subcommittee. Addition of recommendations for the use of recombinant human thrombomodulin to the
"Expert consensus for the treatment of disseminated intravascular coagulation in Japan". Thromb Res 2014;134(04):924-925

301 Krishnan R, Tsubery H, Proschitsky MY, et al. A bacteriophage capsid protein provides a general amyloid interaction motif (GAIM) that binds and remodels misfolded protein assemblies. J Mol Biol 2014;426(13):2500-2519

302 Barber M, Tait RC, Scott J, Rumley A, Lowe GD, Stott DJ. Dementia in subjects with atrial fibrillation: hemostatic function and the role of anticoagulation. J Thromb Haemost 2004;2(11):1873-1878

303 Murthy SB, Jawaid A, Qureshi SU, Schulz PE, Schulz PE. The apolipoprotein 2 allele in Alzheimer's disease: suggestions for a judicious use of antiplatelet and anticoagulant medications. J Am Geriatr Soc 2009;57(06):1124-1125

304 Nilsson KP, Lindgren M, Hammarström P. A pentameric luminescent-conjugated oligothiophene for optical imaging of in vitroformed amyloid fibrils and protein aggregates in tissue sections. Methods Mol Biol 2012;849:425-434

305 Eisenberg D, Jucker M. The amyloid state of proteins in human diseases. Cell 2012;148(06):1188-1203

306 Tycko R, Wickner RB. Molecular structures of amyloid and prion fibrils: consensus versus controversy. Acc Chem Res 2013; 46(07):1487-1496

307 Langkilde AE, Morris KL, Serpell LC, Svergun DI, Vestergaard B. The architecture of amyloid-like peptide fibrils revealed by X-ray scattering, diffraction and electron microscopy. Acta Crystallogr D Biol Crystallogr 2015;71(Pt 4):882-895

308 Bembde AS. A study of plasma fibrinogen level in type-2 diabetes mellitus and its relation to glycemic control. Indian J Hematol Blood Transfus 2012;28(02):105-108 